\title{
Frequency of diet delivery to dairy cows: Effect on nutrient digestion, rumen fermentation, methane production, nitrogen utilization, and milk production
}

\author{
C. Benchaar* (i) and F. Hassanat (1) \\ Agriculture and Agri-Food Canada, Sherbrooke Research and Development Centre, Sherbrooke, QC, Canada J1M 0C8
}

\begin{abstract}
The objective of this study was to examine the effect of frequency of diet delivery to dairy cows on nutrient digestion, rumen fermentation, milk production, nitrogen utilization, enteric methane emission, and manure methane production potential. Twelve lactating cows were used in a replicated $3 \times 3$ Latin square design (35$\mathrm{d}$ period) and offered a TMR ad libitum [56:44 ratio of forage to concentrate, dry matter (DM) basis] once $(0930 \mathrm{~h})$, twice $(0930$ and $2130 \mathrm{~h})$, or 4 times daily $(0930,1300,1630$, and 2130 h). Frequency of diet delivery did not affect intake or apparent total-tract digestibility of DM and nutrients. Likewise, milk production, milk composition (fat, protein, and lactose), and milk production efficiency ( $\mathrm{kg}$ of milk/ $\mathrm{kg}$ of DM intake or $\mathrm{g}$ of milk N/g of $\mathrm{N}$ intake) were not changed by frequency of diet delivery. Although diurnal variation of ruminal $\mathrm{pH}$, total VFA, and acetate molar proportion were influenced by frequency of diet delivery, daily average ruminal $\mathrm{pH}$, total VFA, and acetate and propionate molar proportions were not affected by frequency of diet delivery. Daily enteric $\mathrm{CH}_{4}$ emission averaged 534 $\mathrm{g} / \mathrm{d}$ and was not changed by frequency of diet delivery. Methane energy losses (on gross energy intake basis) were lower when cows received the diet once daily (5.8\%) versus twice or 4 times daily $(6.1 \%)$. Urinary $\mathrm{N}$ excretion was higher for cows receiving the diet 4 times daily compared with cows receiving the diet once or twice daily ( 36 vs. $34 \%$ of $\mathrm{N}$ intake). Frequency of diet delivery had no influence on manure volatile solids excretion or maximal $\mathrm{CH}_{4}$ production potential. Results from this study show that delivering the diet once daily reduces enteric $\mathrm{CH}_{4}$ energy losses compared with twice or 4 times daily, whereas urinary $\mathrm{N}$ losses increased by delivering the diet 4 times daily compared with once or twice daily. However, milk production and maximal
\end{abstract}

Received January 14, 2020.

Accepted April 4, 2020.

*Corresponding author: chaouki.benchaar@canada.ca manure $\mathrm{CH}_{4}$ emission potential were not affected by frequency of diet delivery.

Key words: frequency of diet delivery, methane emissions, dairy cow

\section{INTRODUCTION}

Methane emissions from enteric fermentation and manure management contribute $30 \%$ of Canada's national $\mathrm{CH}_{4}$ emissions (Environment Canada, 2019). Diet manipulation has been shown to influence $\mathrm{CH}_{4}$ production in dairy cows (Brask et al., 2013; Benchaar et al., 2015; Hassanat et al., 2017). When dietary interventions affected DMI or ruminal OM fermentation, the amount and the composition of manure volatile solids (VS) were changed, affecting $\mathrm{CH}_{4}$ emissions from stored manure (Møller et al., 2014; Benchaar and Hassanat, 2019; Hassanat and Benchaar, 2019). However, studies investigating the effect of non-nutritional feeding management practices (e.g., frequency of diet delivery) on $\mathrm{CH}_{4}$ emissions from enteric fermentation and manure storage are scarce.

Under conventional feeding practices, dairy producers offer TMR to dairy cows once or twice daily. Feeding rate $(\mathrm{kg}$ of $\mathrm{DMI} / \mathrm{h})$ and time spent eating $(\mathrm{min} / \mathrm{h})$ are highest immediately after diet delivery (DeVries and von Keyserlingk, 2005; King et al., 2016). Moreover, DeVries et al. (2005) reported that cows spend more time during the day eating when the diet is delivered more frequently. Also, according to Shabi et al. (1998, 1999) and Cabrita et al. (2006), increasing frequency of diet delivery prevents extreme fluctuation of ruminal $\mathrm{pH}$ and metabolite concentrations $\left(\mathrm{VFA}, \mathrm{NH}_{3}\right)$ in ruminal fluid, resulting into a more stable rumen environment. As a result, DMI, fiber digestion, and microbial protein synthesis increase by increasing frequency of diet delivery (Shabi et al., 1998, 1999; Cabrita et al., 2006). These findings indicate that increasing frequency of diet delivery may increase the amount of $\mathrm{CH}_{4}$ emitted daily by dairy cows.

Studies investigating the effect of frequency of diet delivery on enteric $\mathrm{CH}_{4}$ production are very scarce, and no information is available on the effects of frequency of 
diet delivery on $\mathrm{CH}_{4}$ emissions from stored manure. We hypothesized that the increasing frequency of diet delivery would (1) induce a more stable rumen environment, thereby increasing OM degradation in the rumen; (2) increase DMI, nutrient digestion, and milk production; and (3) increase enteric $\mathrm{CH}_{4}$ production $(\mathrm{g} / \mathrm{d})$ but reduce $\mathrm{CH}_{4}$ production potential during manure storage. Therefore, the objective of this study is to investigate the influence of frequency of diet delivery (once, twice, or 4 times per day) on digestion, ruminal fermentation characteristics, $\mathrm{N}$ excretion, milk production, and $\mathrm{CH}_{4}$ emissions from enteric fermentation and stored manure.

\section{MATERIALS AND METHODS}

The study was conducted at the Sherbrooke Research and Development Centre (Sherbrooke, Quebec, Canada). Animal procedures were conducted under the approval of the local Institutional Animal Care Committee and were in accordance with the guidelines of the Canadian Council on Animal Care (Canadian Council on Animal Care, 2009).

\section{Cows, Experimental Design, and Diet}

Twelve multiparous $(3.0 \pm 1.0$ parity) lactating Holstein cows fitted with rumen cannulas $(10 \mathrm{~cm}$, Bar Diamond Inc., Parma, ID) were used in a replicated 3 $\times 3$ Latin square design (35-d period). The cows averaged (mean $\pm \mathrm{SD}$ ) $85 \pm 23.7 \mathrm{DIM}$ at the beginning of the experiment with an average BW of $681 \pm 76 \mathrm{~kg}$ and milk yield of $50 \pm 3.7 \mathrm{~kg} / \mathrm{d}$. During the experiment, cows were housed in individual tiestalls and had free access to water. Cows were fed ad libitum (5\% orts, on an as-fed basis) a TMR consisting of $56 \%$ forage and $44 \%$ concentrate (DM basis; Table 1) formulated to meet the nutrient requirements of cows (NRC, 2001). The experimental treatments were as follows: (1) TMR delivered once daily; (2) TMR delivered twice daily; and (3) TMR delivered 4 times daily. The TMR was delivered at 0930h; 0930 and $2130 \mathrm{~h}$; and 0930, 1300, 1630, and $2130 \mathrm{~h}$ for cows fed once, twice, and 4 times, respectively. The diet was pushed up at 1300, 1630, and $2130 \mathrm{~h}$. Separators were installed between cows to minimize the disruption caused by the different frequencies of diet delivery.

After $14 \mathrm{~d}$ of adaptation to dietary treatments, feed intake, apparent total-tract digestibility, N excretion, milk production and milk composition $(7 \mathrm{~d})$; in sacco ruminal degradability (5 d); rumen fermentation characteristics (2 d); BW (2 d); and $\mathrm{CH}_{4}$ production (5 d) were measured. Because only 2 respiration chambers were available, cows were staggered by $5 \mathrm{~d}$ to facilitate measurements. In addition, measurements (digestibility, $\mathrm{N}$ excretion, rumen fermentation, in sacco ruminal degradability, and $\mathrm{CH}_{4}$ ) were spread over the $21 \mathrm{~d}$ of sampling and data collection. Manure $\mathrm{CH}_{4}$ emissions were measured from manure collected over 2 consecutive days during the last period of the experiment.

\section{Intake, Apparent Total-Tract Digestibility, $N$ Excretion, and $B W$}

Apparent total-tract digestibility and $\mathrm{N}$ excretion were measured as described in Benchaar et al. (2013). Feed consumption was recorded daily by weighing feeds delivered to and refused by the cows. Total collection of feces and urine was performed as described in Benchaar et al. (2013) by fitting cows with harnesses and tubes allowing the collection of feces and urine separately. Samples of the diet, feed ingredients, refusals, and feces were collected daily and stored at $-20^{\circ} \mathrm{C}$. These samples were later thawed, composited by cow within period, freeze-dried, ground to pass a 1-mm screen using a Wiley mill (standard model 4; Arthur M. Thomas,

Table 1. Ingredient and chemical composition of the TMR (\% of DM unless otherwise noted)

\begin{tabular}{|c|c|}
\hline Item & Amount \\
\hline \multicolumn{2}{|l|}{ Ingredient } \\
\hline Corn silage & 24.9 \\
\hline Alfalfa silage & 24.9 \\
\hline Corn grain, ground & 23.1 \\
\hline Protein supplement ${ }^{1}$ & 6.20 \\
\hline Timothy hay, chopped & 6.06 \\
\hline Soybean hulls & 6.02 \\
\hline Soybean meal, $48 \%$ solvent extracted & 5.27 \\
\hline Mineral and vitamin supplement ${ }^{2}$ & 1.57 \\
\hline Rumen inert fat supplement ${ }^{3}$ & 1.19 \\
\hline Calcium carbonate & 0.78 \\
\hline \multicolumn{2}{|l|}{ Chemical composition } \\
\hline $\mathrm{OM}$ & 92.9 \\
\hline $\mathrm{CP}$ & 17.5 \\
\hline $\mathrm{RDP}^{4}(\%$ of $\mathrm{CP})$ & 60.9 \\
\hline $\mathrm{RUP}^{4}(\%$ of $\mathrm{CP})$ & 39.1 \\
\hline $\mathrm{NDF}$ & 30.8 \\
\hline $\mathrm{ADF}$ & 19.9 \\
\hline Starch & 25.4 \\
\hline Gross energy (Mcal/kg of DM) & 4.45 \\
\hline $\mathrm{NE}_{\mathrm{L}}{ }^{4}(\mathrm{Mcal} / \mathrm{kg}$ of DM $)$ & 1.60 \\
\hline
\end{tabular}

${ }^{1}$ Top supplement, composed of $30 \%$ corn gluten meal, $20 \%$ heat-treated soybean, $20 \%$ canola meal, and $30 \%$ dried corn distillers grains (Bélisle Solution Nutrition Inc., St-Mathias, QC, Canada).

${ }^{2}$ Contained $9.27 \%$ Ca, $4.80 \%$ P, $4.80 \% \mathrm{Mg}, 1.57 \%$ S, $12.68 \% \mathrm{Na}, 1.23 \%$ $\mathrm{K}, 23 \mathrm{mg} / \mathrm{kg} \mathrm{I}, 2,014 \mathrm{mg} / \mathrm{kg} \mathrm{Fe}, 440 \mathrm{mg} / \mathrm{kg} \mathrm{Cu}, 1,797 \mathrm{mg} / \mathrm{kg} \mathrm{Mn}$, $2,657 \mathrm{mg} / \mathrm{kg} \mathrm{Zn}, 7 \mathrm{mg} / \mathrm{kg}$ Co, 467,556 IU/ kg vitamin A, 56,669 IU/kg vitamin D, 2,739 IU $/ \mathrm{kg}$ vitamin E, and $20 \mathrm{mg} / \mathrm{kg}$ Se.

${ }^{3}$ Energy Booster 100 (Milk Specialties Global Animal Nutrition, Carpentersville, IL).

${ }^{4}$ Calculated using values from NRC (2001) tables. 
Philadelphia, PA), and analyzed for DM, OM, total $\mathrm{N}, \mathrm{NDF}, \mathrm{ADF}$, starch, and gross energy (GE). Urine (acidified with $50 \% \mathrm{H}_{2} \mathrm{SO}_{4}$ ) was analyzed for total $\mathrm{N}$ content. Cows were weighed at the beginning and end of each experimental period on 2 consecutive days before the a.m. feeding and after the a.m. milking.

\section{In Sacco Ruminal Degradability}

Ruminal degradability of the TMR was determined (6 cows; Latin square design) using the nylon bag procedure as described in Benchaar et al. (2013). Samples were ground to pass a $2-\mathrm{mm}$ screen using a Wiley mill, and $5 \mathrm{~g}(\mathrm{DM})$ were weighed in quadruplicates in polyester bags $(17 \mathrm{~cm} \times 9 \mathrm{~cm} ; 53-\mu \mathrm{m}$ pore size $)$ made of monofilament PeCAP Polyester (Sefar Nitex, Sefar AG, Heiden, Switzerland). Bags were incubated in the ventral sac of the rumen for 2, 4, 8, 16, 24, 48, 72, 96, and $120 \mathrm{~h}$. Bags used for time 0 disappearance were soaked in water at $37^{\circ} \mathrm{C}$ for $5 \mathrm{~min}$ and then treated similarly to the other bags. Residues recovered after incubation were dried at $55^{\circ} \mathrm{C}$ for $48 \mathrm{~h}$ and ground to pass through a 1-mm screen for subsequent determination of DM.

Kinetics of ruminal degradation of DM of the TMR were calculated using a nonlinear model of McDonald (1981). The NLIN procedure of SAS (SAS Institute Inc., Cary, NC) was used to fit the following model:

$$
\begin{gathered}
\mathrm{P}(t)=\mathrm{a}+\mathrm{b}\left(1-\mathrm{e}^{-\mathrm{c}(t-\mathrm{L})}\right) \text { for } t>\mathrm{L} ; \\
\mathrm{P}(t)=\mathrm{a} \text { for } t \leq \mathrm{L}
\end{gathered}
$$

where $\mathrm{P}(t)=$ percentage of DM disappearance from the nylon bag at time $t, \mathrm{a}=$ soluble and rapidly degradable fraction $(\%), \mathrm{b}=$ slowly degradable fraction $(\%), \mathrm{c}=$ fractional rate of disappearance of the fraction $\mathrm{b}$ (per $\mathrm{h}), \mathrm{L}=$ lag time (h), and $t=$ time of incubation (h). The model was fitted using $(\mathrm{a}+\mathrm{b}) \leq 100, \mathrm{~b} \geq 0, \mathrm{c} \geq$ 0 , and $\mathrm{L} \geq 0$ constraints.

The effective ruminal degradability of DM was calculated using the following equation:

Effective ruminal degradability $=a+\left[b c /\left(c+k_{p}\right)\right] \times e^{\left(-k_{p} L\right)}$,

where $k_{p}$ is the ruminal fractional passage rate, calculated from the equations suggested by the NRC (2001).

\section{Ruminal Fermentation Characteristics and Protozoa Enumeration}

Ruminal fluid was collected from each cow before (0 $\mathrm{h}$ ) and $1,2,3,4,6$, and $8 \mathrm{~h}$ after the a.m. meal, as described in Benchaar et al. (2013). A total of $250 \mathrm{~mL}$ was collected from several locations within the rumen using a $50-\mathrm{mL}$ syringe screwed to a stainless steel tube ending with a probe covered by a fine metal mesh (RT Rumen Fluid Collection Tube, Bar Diamond Inc.). Ruminal fluid was subsampled $(15 \mathrm{~mL})$ and frozen at $-20^{\circ} \mathrm{C}$ immediately for later determination of VFA concentrations. Another subsample $(15 \mathrm{~mL})$ was acidified to $\mathrm{pH} 2$ with $50 \%$ sulfuric acid and frozen at $-20^{\circ} \mathrm{C}$ for later determination of $\mathrm{NH}_{3}$ concentration.

Protozoa were counted from ruminal content collected before the a.m. meal as described in Benchaar et al. (2013). Ruminal content (approximately $1 \mathrm{~L}$ ) was strained through 4 layers of cheesecloth, and a $5-\mathrm{mL}$ portion of the strained ruminal fluid was preserved using $5 \mathrm{~mL}$ of methyl green formalin-saline solution for protozoa enumeration (Ogimoto and Imai, 1981). Protozoa samples were stored at room temperature in darkness until counting. Protozoa were microscopically enumerated using a counting chamber (Neubauer Improved Bright-Line counting cell, 0.1-mm depth; Hausser Scientific, Horsham, PA), and genera were identified as outlined by Dehority (1993).

Ruminal pH was measured continuously for $48 \mathrm{~h}$ using eCow bolus system (eBolus, eCow Ltd., Exeter, UK). The system consisted of eCow bolus probes, handset (Moto G Model XT1032, Motorola, Chicago, IL) equipped with Hathor V4.8 software, and an adapter (dongle) fitted with antenna as described by Falk et al. (2016). The probes were calibrated to $\mathrm{pH} 4.00$ and 7.00 at $39^{\circ} \mathrm{C}$ prior to use. The probes were attached to a $0.5-\mathrm{kg}$ metal weight, to ensure that they would always be immersed in the ruminal fluid, and then placed in the ventral sac of the rumen. Ruminal $\mathrm{pH}$ was recorded every $15 \mathrm{~min}$. After $48 \mathrm{~h}$, the probes were removed and data downloaded. The probes were then immersed in $\mathrm{pH} 4.00$ and $\mathrm{pH} 7.00$ buffers kept at $39^{\circ} \mathrm{C}$, and the probe drift did not exceed \pm 0.05 . The $\mathrm{pH}$ data were summarized as mean $\mathrm{pH}$, minimum $\mathrm{pH}$, maximum $\mathrm{pH}$, time spent below $\mathrm{pH}$ 6.0, time spent below $\mathrm{pH} 5.6$, and time spent below pH 5.2 (Plaizier et al., 2001; Keunen et al., 2002).

\section{Milk Production and Milk Composition}

Cows were milked twice daily at 0700 and $1930 \mathrm{~h}$ in their stalls. Milk production was recorded at each milking, and milk data recorded during the $7 \mathrm{~d}$ of apparent total-tract digestibility measurement were used for the statistical analysis. Milk samples were taken from each cow at each milking, stored at $4^{\circ} \mathrm{C}$ with a preservative (2-bromo-2-nitropropan-1,3-diol), and sent to a commercial laboratory (Lactanet, Ste-Anne-de-Bellevue, 
QC, Canada) for analysis of fat, protein, lactose, MUN, and SCC.

\section{Enteric Methane Production}

Respiration chambers measured $4.09 \mathrm{~m}$ long $\times 2.95$ $\mathrm{m}$ wide $\times 2.84 \mathrm{~m}$ high. When doors were closed, air entered the chamber through a ventilation duct and exited through an exhaust. Air temperature within the chamber was maintained at $17 \pm 0.5^{\circ} \mathrm{C}$. Airflow into and out of the chamber was measured using inline mass flowmeters (FT2; Fox Thermal Instruments Inc., Marina, CA) and maintained at $180 \pm 10 \mathrm{~m}^{3} / \mathrm{h}$. Methane concentration was continuously measured at the air entrance and exhaust ducts using $\mathrm{CH}_{4}$ analyzers (SERVOPRO 4100; Servomex, Brighton, UK). The amount of $\mathrm{CH}_{4}$ entering and leaving the chamber was calculated by multiplying the concentration of $\mathrm{CH}_{4}$ by the airflow at entrance and at exhaust. The difference between the incoming and outgoing mass of $\mathrm{CH}_{4}$ corresponded to the amount of enteric $\mathrm{CH}_{4}$ emitted in each chamber by the animal. Chambers were calibrated at the beginning of each experimental period by releasing known amounts of $\mathrm{CH}_{4}$ in each empty chamber. Recovered amounts of $\mathrm{CH}_{4}$ were calculated from the difference between incoming and outgoing $\mathrm{CH}_{4}$. The recovered amounts averaged $96 \%( \pm 1.0)$ and $105 \%( \pm 2.4)$ for the first and second chamber, respectively. The calibration factors (i.e., to adjust each chamber to $100 \%$ recovery) were used to correct $\mathrm{CH}_{4}$ emissions data. A small positive pressure was generated inside each chamber to prevent inflow of gases to the chambers. Methane was recorded every minute over 5 consecutive days, and fluxes were averaged to derive $24-\mathrm{h} \mathrm{CH}_{4}$ emissions. Cows were preconditioned to the respiration chambers before the beginning of the experiment. To reduce the effect of confinement on animal behavior, the chambers were equipped with windows and speakers so the cow in the chamber could see and hear her peers. Cows entered the chambers $18 \mathrm{~h}$ before starting $\mathrm{CH}_{4}$ measurements. Within each chamber, the cow was kept in a tiestall that measured $1.82 \mathrm{~m}$ long $\times 1.60 \mathrm{~m}$ wide, elevated from the floor by $25 \mathrm{~cm}$. Manure was collected in a stainless steel box placed below and to the rear of each stall. Farm personnel accessed the chambers to feed and milk the cows and remove the manure. The doors were kept open for 1 to 1.5 min to allow exchange of material in and out of the chambers. This resulted in interruptions of flux measurements for 15 to $30 \mathrm{~min}$, which is the time required for gas concentrations to reach steady state. These interruptions had little effect on daily emissions, because fluxes were calculated every minute and used to derive the 24-h emissions values.
Cows in the chambers were milked twice daily, had free access to water, and were fed for ad libitum intake $(5 \%$ orts on an as-fed basis). Offered feed and orts were weighed daily to determine feed consumption. Samples of feed offered and orts were collected, pooled across days, and kept frozen for later determination of DM and GE concentrations.

The relationship between frequency of diet delivery and rate of $\mathrm{CH}_{4}$ emission, by treatment, was examined using the exponential equation described by Thornley and France (2007):

$$
\begin{gathered}
\text { Methane production rate }(\mathrm{g} / \mathrm{h})= \\
\mathrm{a} \exp \left[\mathrm{bc}^{-1}\left(1-\mathrm{e}^{-\mathrm{ct}}\right)-\mathrm{d}_{t}\right]
\end{gathered}
$$

where $\mathrm{a}=$ initial $\mathrm{CH}_{4}$ production rate $(\mathrm{g} / \mathrm{h})$ before diet delivery; $t=$ time of day ( $\mathrm{h}$ ); and $\mathrm{b}, \mathrm{c}$, and $\mathrm{d}=$ kinetic parameters characterizing diurnal variation in $\mathrm{CH}_{4}$ emission $(\mathrm{g} / \mathrm{h})$. Kinetic parameters obtained from the previous equation were used to calculate time of $\mathrm{CH}_{4}$ production peak $(\mathrm{h})$, peak $\mathrm{CH}_{4}$ production rate $(\mathrm{g} / \mathrm{h})$, and relative rate of decline (per h) of $\mathrm{CH}_{4}$ using the following equations:

Time of $\mathrm{CH}_{4}$ production peak $(\mathrm{h})=\mathrm{c}^{-1} \ln (\mathrm{b} / \mathrm{d})$,

Peak $\mathrm{CH}_{4}$ production rate $(\mathrm{g} / \mathrm{h})=$ $a(b / d)^{b / c} \exp \left[c^{-1}(b-d)\right]$,

Relative rate of decline (per $\mathrm{h})=$ $\mathrm{b} \exp \left[-\mathrm{c}\left(t+t_{\mathrm{f}}\right) / 2\right]-\mathrm{d}$,

where $t_{\mathrm{f}}$ is final measurement time $(\mathrm{h})$.

\section{Manure Methane Production}

To determine $\mathrm{CH}_{4}$ emissions of stored manure, feces and urine and were collected from each cow as described previously. Feces and nonacidified urine were weighed daily, sampled (4\% of the amount excreted), mixed based on the daily excreted feces-to-urine ratio (on a fresh-weight basis), and then pooled over the 2 collection days for each cow. Subsamples were taken and stored at $-20^{\circ} \mathrm{C}$ and subsequently freeze-dried and ground to pass a 1-mm screen using a Wiley mill for later determination of DM, VS, and NDF. The mixture of feces and urine of each cow was mixed manually on a fresh-weight basis with psychrophilic residual sludge (1:1) obtained from a manure storage facility at the dairy operation of the Sherbrooke Research and De- 
velopment Centre. In this study, the mixture of feces, urine, and residual sludge was identified as manure.

The manure was transferred under anaerobic conditions $\left(\mathrm{O}_{2}\right.$-free $\left.\mathrm{N}_{2}\right)$ into 500-mL glass bottles (3 replicates per cow; $250 \mathrm{~g}$ in each bottle), sealed with butyl rubber stoppers and aluminum seals (Wheaton Industries Inc., Millville, NJ), and incubated at $20^{\circ} \mathrm{C}$ for $17 \mathrm{wk}$ in a controlled-environment chamber. Blank bottles $(\mathrm{n}=3)$ containing residual sludge $(250 \mathrm{~g})$ were treated similarly for measurement of gas production. Thus, in total, 39 bottles were used in this study. Concentration of DM in residual sludge was $3.9 \%$ and was composed (on DM basis) of $71 \%$ VS and $28 \%$ NDF. Methane emissions from the residual sludge after $17 \mathrm{wk}$ of incubation were negligible and averaged $8.7 \mathrm{~L} / \mathrm{kg}$ of VS.

Gas pressure in the bottle headspace was measured daily using a digital pressure gauge (Ashcroft 2089, Ashcroft Inc., Stratford, CT), and the volume of gas produced was calculated according to the following equation:

$$
\mathrm{P}_{1} \mathrm{~V}_{1}=\mathrm{P}_{2} \mathrm{~V}_{2},
$$

where $\mathrm{P}_{1}=$ atmospheric pressure, $\mathrm{V}_{1}=$ volume of gas produced at atmospheric pressure, $\mathrm{P}_{2}=$ pressure of gas measured at specific incubation day, and $\mathrm{V}_{2}=$ volume of headspace of the bottle.

Headspace gas was sampled using a syringe connected to the pressure gauge by a sampling valve. The collected gas sample was then forced into 6-mL screw-capped vacuum vials (Labco Ltd., Lampeter, UK) covered with a rubber septum (National Scientific, Rockwood, TN) for measurement of $\mathrm{CH}_{4}$ concentration. Gas pressure in the bottle headspace was then reduced to room pressure by leaving the sampling syringe open for $2 \mathrm{~min}$. Gas production from blanks was not subtracted from gas produced from the experimental bottles.

\section{Chemical Analyses}

Dry matter content was determined by drying samples in a vacuum oven at $100^{\circ} \mathrm{C}$ overnight (AOAC International, 2005; method 934.01). Ash content was determined by sample incineration at $550^{\circ} \mathrm{C}$ overnight in a muffle furnace (AOAC International, 2005; method 942.05), and the OM content was calculated as the difference between 100 and the percentage of ash. Crude protein $(\mathrm{N} \times 6.25)$ was determined using the macroKjeldahl procedure (AOAC International, 2005; method 954.01). The concentration of NDF was determined as described by Van Soest et al. (1991) with the use of sodium sulfite and with the inclusion of heat-stable $\alpha$-amylase. The ADF content was determined according to AOAC International (2005; method 973.18). The
NDF and ADF procedures were adapted for use in an Ankom200 Fiber Analyzer (Ankom Technology Corp., Fairport, NY). The concentration of starch was determined colorimetrically according to the procedure of AOAC International (2005; method 996.11). Gross energy was determined using an oxygen bomb calorimeter (model 6200, Parr Instrument Company, Moline, IL). The concentration of $\mathrm{N}$ in acidified urine samples was determined by micro-Kjeldahl analysis (AOAC International, 2005). Analysis of VFA was performed using a gas chromatograph equipped with a flame ionization detector and autoinjector (6850 network GC system, Agilent Technologies, Mississauga, ON, Canada) fitted with DB-FFAP column $(30 \mathrm{~m} \times 0.250 \mathrm{~mm} \times 0.25$ $\mu \mathrm{m}$; Agilent Technologies) as in Benchaar et al. (2015). Ammonia concentration was determined as in Weatherburn (1967). Protein, fat, lactose, urea N, and SCC in milk samples were analyzed by infrared spectroscopy (MilkoScan FT 6000; Foss Electric, Hillerød, Denmark). Milk composition was corrected for differences in milk yield between a.m. and p.m. milkings.

\section{Statistical Analyses}

All data were analyzed using the MIXED procedure of SAS. For the feeding trial data, the statistical model included frequency of diet delivery and period as fixed effects, and cow was considered as random effect. Ruminal fermentation characteristics ( $\mathrm{pH}$, VFA, $\mathrm{NH}_{3}$ ) data were analyzed as repeated measures using the same model, with the addition of the fixed effects of day, sampling time (hour), and all interactions. The $\mathrm{CH}_{4}$ data were also analyzed as repeated measures with the inclusion of the fixed effects of day and day $\times$ treatment interaction. The appropriate covariance structure used for repeated-measures analyses was chosen according to the type of repeated measurement (single or double) and sampling distance (equal or unequal) and to achieve lowest Akaike, corrected Akaike, and Bayesian information criteria values. The covariance structure used cow within treatment $\times$ period as subject of the repeated measures. For the manure trial, the statistical model included frequencies of diet delivery as fixed effects, and cow was the experimental unit. Significant effects of treatment were declared at $P \leq$ 0.05 , with tendencies at $0.05<P \leq 0.10$, using the Tukey test for multiple comparisons.

\section{RESULTS AND DISCUSSION}

\section{Intake and Apparent Total-Tract Digestibility}

Frequency of diet delivery had no effect on intake of DM $(26.3 \mathrm{~kg} / \mathrm{d}), \mathrm{CP}(4.6 \mathrm{~kg} / \mathrm{d}), \operatorname{NDF}(8.1 \mathrm{~kg} / \mathrm{d})$, or starch $(6.7 \mathrm{~kg} / \mathrm{d})$, as presented in Table 2 . Literature 
Table 2. Intake and apparent total-tract digestibility of nutrients in lactating cows receiving the diet once, twice, or 4 times daily

\begin{tabular}{|c|c|c|c|c|}
\hline \multirow[b]{2}{*}{ Item } & \multicolumn{3}{|c|}{ Daily frequency of diet delivery } & \multirow[b]{2}{*}{ SEM } \\
\hline & Once & Twice & 4 Times & \\
\hline \multicolumn{5}{|c|}{ Intake $(\mathrm{kg} / \mathrm{d}$, unless otherwise noted) } \\
\hline DM & 26.6 & 26.1 & 26.2 & 0.47 \\
\hline $\mathrm{DM}(\%$ of $\mathrm{BW})$ & 3.81 & 3.74 & 3.75 & 0.118 \\
\hline $\mathrm{OM}$ & 24.7 & 24.0 & 24.0 & 0.48 \\
\hline $\mathrm{CP}$ & 4.65 & 4.52 & 4.50 & 0.095 \\
\hline $\mathrm{NDF}$ & 8.23 & 8.02 & 8.08 & 0.172 \\
\hline $\mathrm{ADF}$ & 5.29 & 5.15 & 5.24 & 0.107 \\
\hline Starch & 6.79 & 6.60 & 6.60 & 0.150 \\
\hline Gross energy (Mcal/d) & 118 & 115 & 115 & 2.26 \\
\hline \multicolumn{5}{|l|}{ Digestibility (\%) } \\
\hline DM & 70.6 & 70.5 & 70.5 & 0.32 \\
\hline $\mathrm{OM}$ & 72.1 & 72.0 & 72.0 & 0.31 \\
\hline $\mathrm{CP}$ & 68.1 & 68.3 & 67.9 & 0.62 \\
\hline $\mathrm{NDF}$ & 52.3 & 51.7 & 52.1 & 0.83 \\
\hline $\mathrm{ADF}$ & 50.3 & 49.5 & 50.1 & 0.94 \\
\hline Starch & 96.9 & 97.1 & 96.9 & 0.20 \\
\hline Gross energy & 69.0 & 69.0 & 69.0 & 0.33 \\
\hline
\end{tabular}

data on the effect of feeding frequency on DMI have been variable among studies. In agreement with our findings, studies using cows in tiestalls (Robinson and Sniffen, 1985; Klusmeyer et al., 1990; Judy et al., 2018) reported no change in DMI among cows receiving diets once, twice, or 4 times daily. However, our results disagree with those of Shabi et al. (1999) and Crompton et al. (2011), who reported an increase in DMI when cows housed in tiestalls were fed 4 times versus once daily. On the other hand, when using cows in freestalls, some studies reported no effect of frequency of diet delivery on DMI (DeVries et al., 2005; Crossley et al., 2018), but others (Phillips and Rind, 2001; Mäntysaari et al., 2006) observed a decline in DMI when cows received diets 4 and 5 times daily versus once daily. Compared with a freestall system, social interaction between cows in tiestalls is minimal, which affects feeding activities and consequently DMI, explaining the lack of effect of feeding frequency on DMI observed in our study.

Apparent total-tract digestibility of OM, CP, NDF, and starch was not affected by frequency of diet delivery, averaging $72 \%, 68 \%, 52 \%$, and $97 \%$, respectively (Table 2). Previous studies (Robinson and Sniffen, 1985; Le Liboux and Peyraud, 1999; Judy et al., 2018) reported no effect of frequency of diet delivery on DM and nutrient digestibility in cows fed a high dietary forage proportion $(\geq 54 \%)$. The diet used in the current study contained $56 \%$ forage. Other studies using high concentrate proportion diets $(\geq 51 \%)$ observed an increase in DM, NDF, and CP digestibility when the diet was delivered 4 times versus twice daily (Shabi et al., 1999) or versus once daily (Dhiman et al., 2002).

\section{Ruminal Fermentation Characteristics}

Because interactions between treatment and measurement day were not significant for any of the ruminal fermentation characteristics, only averages of the 2-d measurements were reported. Diurnal evolution of ruminal $\mathrm{pH}$ (Figure 1) was altered by changing frequency of diet delivery (treatment $\times$ sampling time interaction, $P<0.01$ ). Cows receiving the diet 4 times daily had higher ruminal $\mathrm{pH}$ at 3 and $4 \mathrm{~h}$ after the a.m. feeding compared with cows receiving the diet once or twice daily, but no difference was observed between cows receiving the diet once versus twice daily. Cows receiving the diet twice daily had higher ruminal $\mathrm{pH}$ at $9,10,11$, and $12 \mathrm{~h}$ after the a.m. meal compared with cows receiving the diet once or 4 times daily, whereas no difference was observed between cows receiving the diet once versus 4 times daily. However, changing frequency of diet delivery had no effect on average (6.03), minimum (5.49), or maximum (6.49) daily ruminal $\mathrm{pH}$ (Table 3). Frequency of diet delivery had no effect on daily duration of ruminal $\mathrm{pH}<6.0$ (average $10.3 \mathrm{~h} / \mathrm{d}$ ) or duration of ruminal $\mathrm{pH}<5.6$ (average $2.1 \mathrm{~h} / \mathrm{d}$ ).

Except for molar proportion of propionate, significant treatment $\times$ sampling time interactions $(P \leq 0.02)$ were observed for total VFA concentration (Figure 2) and molar proportions of individual VFA. At $3 \mathrm{~h}$ after the a.m. meal, ruminal fluid of cows receiving the diet 4 times daily contained lower $(P=0.02)$ total VFA concentration compared with cows receiving the diet once or twice daily. Total VFA concentration was also lower $(P<0.01)$ at $8 \mathrm{~h}$ after the a.m. meal in cows receiving 


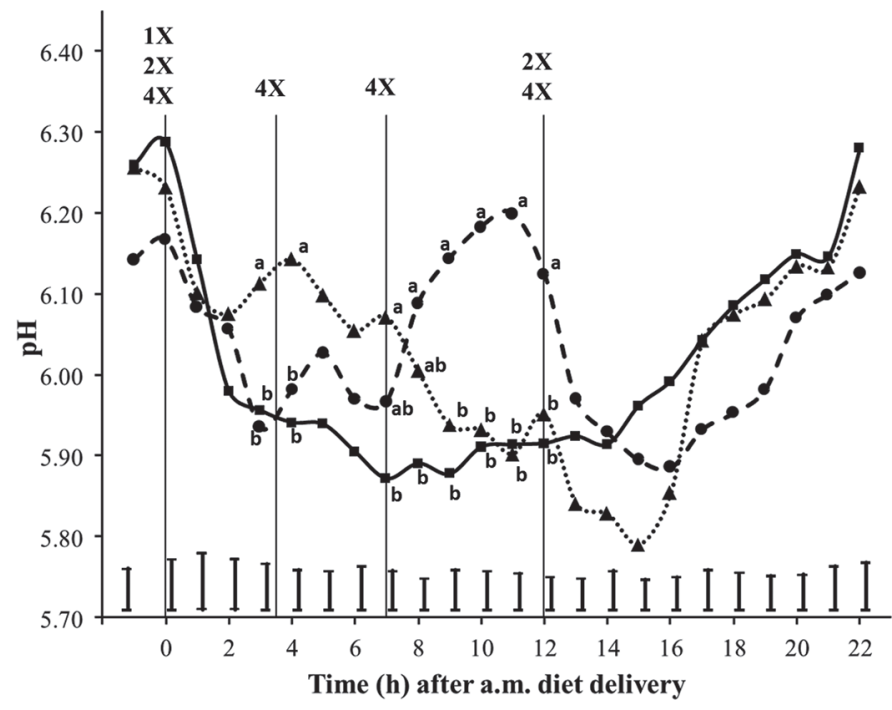

Figure 1. Ruminal $\mathrm{pH}( \pm \mathrm{SEM})$ in lactating cows receiving the diet once (1X; $\mathbf{\square})$, twice $(2 \mathrm{X} ; \boldsymbol{\bullet})$, or 4 times $(4 \mathrm{X} ; \mathbf{\Delta})$ daily. ${ }^{\mathrm{a}, \mathrm{b}} \mathrm{P} \leq 0.05$.

the diet twice daily compared with cows receiving the diet once or 4 times daily.

Molar proportion of acetate was higher $(P \leq 0.02)$ at 2,3 , and $4 \mathrm{~h}$ after the a.m. meal in cows receiving the diet 4 times a day compared with cows receiving the diet once or twice daily (Figure 3 ). These diurnal differences in ruminal $\mathrm{pH}$, total VFA concentration, and acetate molar proportion coincided with the amount of fermentable OM ingested as affected by frequency of diet delivery at the specified time of the day. Indeed, at 2 and $3 \mathrm{~h}$ after the a.m. meal, cows receiving the diet 4 times daily had access only to $25 \%$ of their diet, which resulted in higher ruminal $\mathrm{pH}$ and lower total VFA concentration in the rumen, compared with cows receiving the diet once or twice daily who had access to $100 \%$ and $50 \%$ of their diet, respectively. At $8 \mathrm{~h}$ after the a.m. meal, cows receiving the diet twice daily had access to only $50 \%$ of their diet, which resulted in higher ruminal $\mathrm{pH}$ and lower total VFA concentration in the rumen, compared with cows receiving the diet

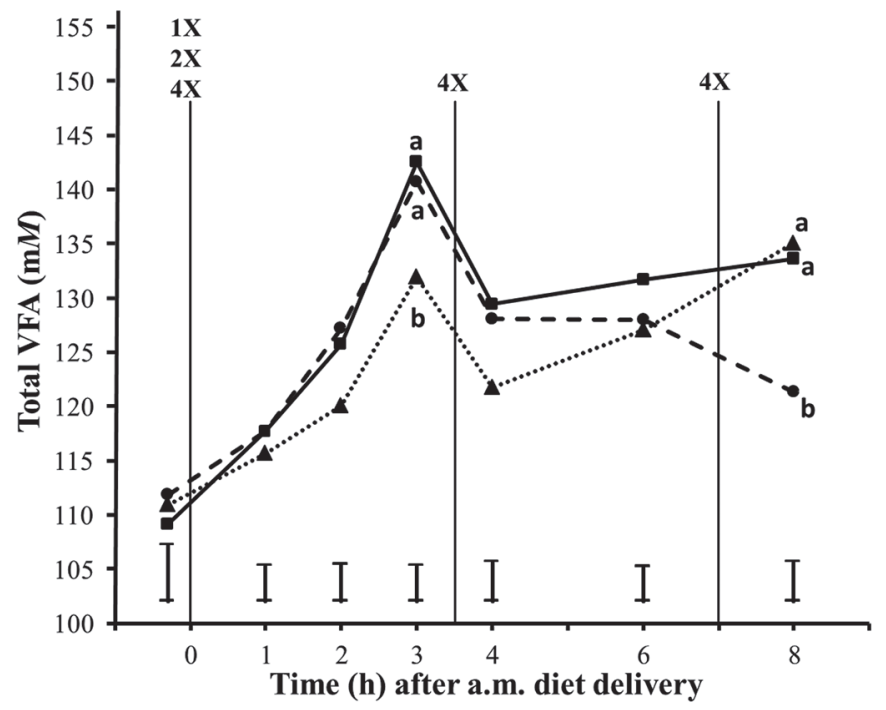

Figure 2. Ruminal total VFA concentration $( \pm \mathrm{SEM})$ in lactating cows receiving the diet once $(1 \mathrm{X} ; \mathbf{\square})$, twice $(2 \mathrm{X} ; \boldsymbol{\bullet})$, or 4 times $(4 \mathrm{X}$; ム) daily. ${ }^{\mathrm{a}, \mathrm{b}} \mathrm{P} \leq 0.05$.

once or 4 times daily (access to $100 \%$ and $75 \%$ of the diet, respectively). Similar effects of frequency of diet delivery on diurnal variation of ruminal $\mathrm{pH}$ and total VFA concentration have previously been reported for steers fed twice versus 8 times daily (Bragg et al., 1986) and for cows fed twice versus 12 times daily (French and Kennelly, 1990).

Overall, daily total VFA concentration, molar proportions of acetate and propionate, and the acetate: propionate ratio were not affected by frequency of diet delivery and averaged $125 \mathrm{mM}, 62,23 \mathrm{~mol} / 100 \mathrm{~mol}$, and 2.8:1, respectively (Table 4 ). Molar proportion of butyrate was lower $(P=0.05)$ in cows receiving the diet 4 times daily compared with cows receiving the diet twice daily, but not different from cows receiving the diet once daily. In agreement, several studies reported no effect of frequency of diet delivery on daily ruminal $\mathrm{pH}$, total VFA concentration, or molar proportion of individual VFA (Le Liboux and Peyraud, 1999;

Table 3. Ruminal $\mathrm{pH}$ in lactating cows receiving the diet once, twice, or 4 times daily

\begin{tabular}{|c|c|c|c|c|}
\hline \multirow[b]{2}{*}{ Item } & \multicolumn{3}{|c|}{ Daily frequency of diet delivery } & \multirow[b]{2}{*}{ SEM } \\
\hline & Once & Twice & 4 Times & \\
\hline \multicolumn{5}{|l|}{$\mathrm{pH}$} \\
\hline Mean & 6.02 & 6.04 & 6.04 & 0.050 \\
\hline Minimum & 5.52 & 5.49 & 5.48 & 0.053 \\
\hline Maximum & 6.51 & 6.48 & 6.47 & 0.055 \\
\hline Time $\mathrm{pH}<6.0(\mathrm{~h} / \mathrm{d})$ & 10.94 & 10.50 & 9.48 & 1.718 \\
\hline Time $\mathrm{pH}<5.6(\mathrm{~h} / \mathrm{d})$ & 2.21 & 2.17 & 2.00 & 0.915 \\
\hline Time $\mathrm{pH}<5.2(\mathrm{~h} / \mathrm{d})$ & 0.07 & 0.01 & 0.05 & 0.039 \\
\hline
\end{tabular}


Table 4. Total VFA concentration, VFA molar proportions, $\mathrm{NH}_{3}$ concentration, and protozoa counts of ruminal fluid in lactating cows receiving the diet once, twice, or 4 times daily

\begin{tabular}{|c|c|c|c|c|}
\hline \multirow[b]{2}{*}{ Item } & \multicolumn{3}{|c|}{ Daily frequency of diet delivery } & \multirow[b]{2}{*}{ SEM } \\
\hline & Once & Twice & 4 Times & \\
\hline Total VFA $(\mathrm{m} M)$ & 127 & 125 & 123 & 2.6 \\
\hline \multicolumn{5}{|l|}{ VFA $(\mathrm{mol} / 100 \mathrm{~mol})$} \\
\hline Acetate $(\mathrm{A})$ & 61.7 & 61.4 & 62.4 & 0.89 \\
\hline Propionate $(\mathrm{P})$ & 22.8 & 23.0 & 22.6 & 0.93 \\
\hline Butyrate & $10.8^{\mathrm{ab}}$ & $11.0^{\mathrm{a}}$ & $10.4^{\mathrm{b}}$ & 0.23 \\
\hline Valerate & $1.62^{\mathrm{a}}$ & $1.57^{\mathrm{ab}}$ & $1.54^{\mathrm{b}}$ & 0.033 \\
\hline Branched-chain $\mathrm{VFA}^{1}$ & 3.08 & 3.01 & 3.08 & 0.073 \\
\hline $\mathrm{A}: \mathrm{P}$ ratio & 2.77 & 2.75 & 2.85 & 0.143 \\
\hline $\mathrm{NH}_{3}(\mathrm{~m} M)$ & $12.6^{\mathrm{a}}$ & $11.3^{\mathrm{b}}$ & $11.1^{\mathrm{b}}$ & 0.49 \\
\hline \multicolumn{5}{|l|}{ Protozoa (cells $\left.\times 10^{3} / \mathrm{mL}\right)$} \\
\hline Total & $531^{\mathrm{b}}$ & $629^{\mathrm{a}}$ & $522^{\mathrm{b}}$ & 73.2 \\
\hline Entodiniomorphs & $527^{\mathrm{b}}$ & $624^{\mathrm{a}}$ & $518^{\mathrm{b}}$ & 72.6 \\
\hline Holotrichs $^{2}$ & 4.65 & 4.79 & 3.68 & 1.160 \\
\hline
\end{tabular}

$\overline{\mathrm{a}, \mathrm{b}}$ Means within rows with different superscripts differ $(P<0.05)$.

${ }^{1}$ Branched-chain VFA = isobutyrate + isovalerate.

${ }^{2}$ Holotrichs $=$ isotrichs and dasytrichs.

Dhiman et al., 2002; Macmillan et al., 2017). Others reported a decline in ruminal $\mathrm{pH}$ associated with an increase in total VFA concentration and acetate and propionate molar proportions with increasing frequency of diet delivery (Froetschel et al., 1990; Klusmeyer et al., 1990).

Significant treatment $\times$ sampling time interactions $(P<0.01)$ were also observed for $\mathrm{NH}_{3}$ concentration (Figure 4). At 1, 2, 3, and $4 \mathrm{~h}$ after the a.m. meal, $\mathrm{NH}_{3}$ concentration was lower $(P \leq 0.02)$ in cows receiving

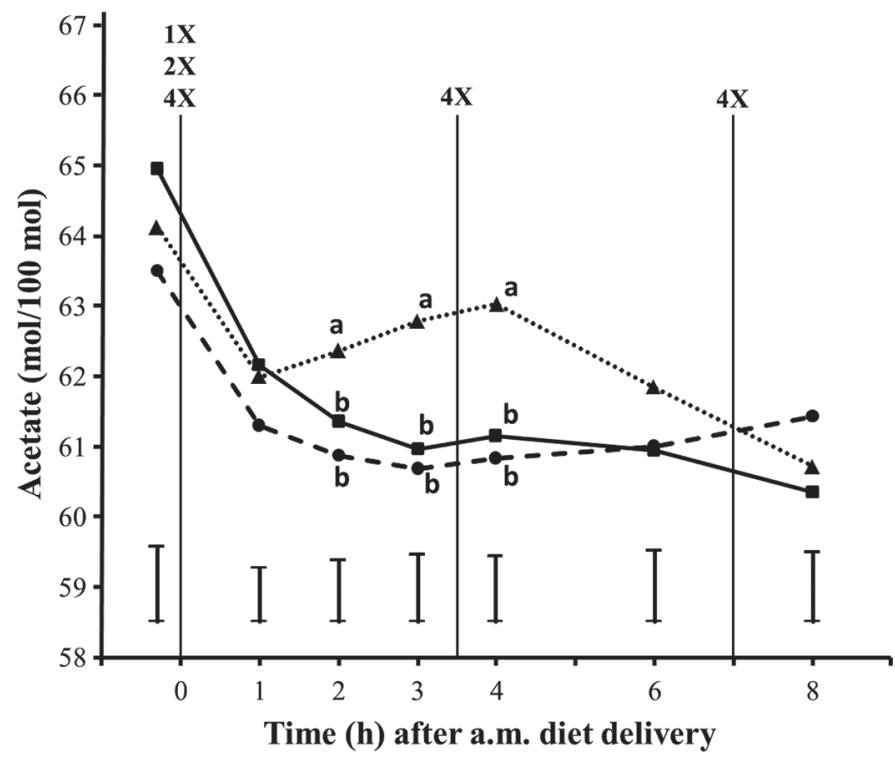

Figure 3. Ruminal acetate molar proportion $( \pm$ SEM $)$ in lactating cows receiving the diet once $(1 \mathrm{X} ; \mathbf{\square})$, twice $(2 \mathrm{X} ; \boldsymbol{\bullet})$, or 4 times (4X; ム) daily. ${ }^{\mathrm{a}, \mathrm{b}} \mathrm{P} \leq 0.05$. the diet 4 times daily compared with cows receiving the diet once or twice daily, but not different between cows receiving the diet once or twice daily. Delivering the diet twice daily reduced $(P=0.02)$ ruminal $\mathrm{NH}_{3}$ concentration at $6 \mathrm{~h}$ after the a.m. meal compared with delivering the diet once or 4 times daily, but no difference was observed between delivering the diet once or 4 times daily. At $8 \mathrm{~h}$ after the a.m. meal, $\mathrm{NH}_{3}$ concentration was higher $(P<0.01)$ in cows receiving the diet 4 times daily compared with cows receiving the diet once or twice daily, and higher in cows receiving the diet once daily versus twice daily. Similar diurnal variation in molar proportion of branched-chain VFA were also observed (data not shown). These diurnal differences in ruminal $\mathrm{NH}_{3}$ concentration and molar proportion of branched-chain VFA coincided with the amount of CP ingested as affected by frequency of diet delivery and at the specified time of day. Similar diurnal variation in $\mathrm{NH}_{3}$ concentration have previously been reported in steers fed twice versus 8 times daily (Bragg et al., 1986) or fed twice versus 12 times daily (Cecava et al., 1990), and among dairy cows fed twice versus 6 times daily (Le Liboux and Peyraud, 1999) or fed concentrates once, twice, or 4 times daily (Yang and Varga, 1989).

Average daily ruminal $\mathrm{NH}_{3}$ concentration was higher $(P=0.01)$ in cows receiving the diet once daily compared with cows receiving the diet twice or 4 times daily, but no difference was observed when the diet was delivered twice or 4 times daily (Table 4 ). In accordance, Ulyatt et al. (1984) reported that increasing frequency of diet delivery to sheep reduced ruminal $\mathrm{NH}_{3}$ concentration. Other studies reported no effect of frequency of diet delivery on ruminal $\mathrm{NH}_{3}$ concentra- 
tion (Froetschel and Amos, 1991; Dhiman et al., 2002; Macmillan et al., 2017). It is worth mentioning that differences in $\mathrm{NH}_{3}$ concentration between cows receiving the diet once daily versus 4 times daily can also be related to the quantity of diet delivered to cows relative to the duration of ruminal fluid sampling in this study. Cows receiving the diet once daily had access to $100 \%$ of the diet during rumen fluid sampling (before to 8 $\mathrm{h}$ after the a.m. meal), resulting in greater consumption of dietary $\mathrm{CP}$ compared with cows receiving the diet twice or 4 times daily (i.e., access to $50 \%$ and $75 \%$ of the diet, respectively, for the same duration). Branched-chain VFA molar proportion averaged 3.1 $\mathrm{mol} / 100 \mathrm{~mol}$ and was not affected by frequency of diet delivery (Table 4).

Populations of total protozoa and entodiniomorphs were higher $(P=0.03$ and $P=0.03$, respectively $)$ in cows receiving the diet twice daily versus once or 4 times daily, but not different when cows received the diet once or 4 times daily (Table 4 ). Holotrichs populations (isotrichs and dasytrichs) were not affected by frequency of diet delivery (average of $4.37 \times 10^{3}$ cell/ $\mathrm{mL}$ ). Conversely, Bragg et al. (1986) reported that increasing frequency of delivery of a TMR to steers from twice to 8 times daily had no effect on the rumen protozoa population. Likewise, Yang and Varga (1989) also reported that increasing frequency of concentrates delivery to cows from once to 4 times per day had no effect on the rumen protozoa population.

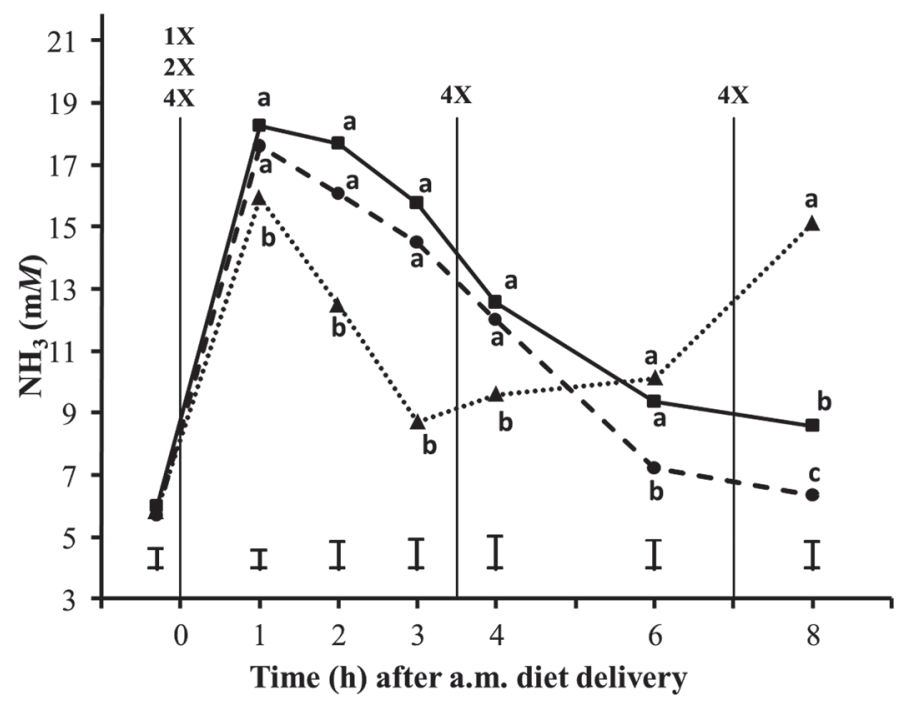

Figure 4. Ruminal $\mathrm{NH}_{3}$ concentration $( \pm \mathrm{SEM})$ in lactating cows receiving the diet once $(1 \mathrm{X} ; \boldsymbol{\square})$, twice $(2 \mathrm{X} ; \bullet)$, or 4 times $(4 \mathrm{X} ; \boldsymbol{\Delta})$ daily. ${ }^{\mathrm{a}-\mathrm{c}} P \leq 0.05$.
Table 5. In sacco DM degradation kinetic parameters of TMR in lactating cows receiving the diet once, twice, or 4 times daily

\begin{tabular}{lcccc}
\hline & \multicolumn{2}{c}{ Daily frequency of diet delivery } & \\
\cline { 2 - 4 } Item $^{1}$ & Once & Twice & 4 Times & \multirow{2}{*}{ SEM } \\
\hline a (\%) & 45.1 & 45.3 & 45.5 & 0.25 \\
b (\%) & 44.2 & 43.7 & 43.5 & 0.49 \\
c (per h) & 0.042 & 0.038 & 0.041 & 0.0012 \\
ERD (\%) & 62.8 & 62.0 & 62.8 & 0.15 \\
\hline
\end{tabular}

${ }^{1} \mathrm{a}=$ soluble and rapidly degradable fraction; $\mathrm{b}=$ slowly degradable fraction; $\mathrm{c}=$ fractional rate of disappearance of the fraction $\mathrm{b} ; \mathrm{ERD}=$ effective ruminal degradability.

\section{In Sacco Ruminal Degradability}

Parameters of in sacco ruminal DM degradability of the diet are presented in Table 5. Soluble and rapidly degradable fraction, slowly degradable fraction, and fractional degradation rate averaged $45.3 \%, 43.8 \%$, and $0.040 / \mathrm{h}$, respectively, and were not affected by frequency of diet delivery. Consequently, frequency of diet delivery has no effect on effective ruminal DM degradability of the diet (averaged 62.5\%). These results are consistent with the absence of an effect of frequency of diet delivery on ruminal total VFA concentration. Dehority and Tirabasso (2001) reported that increasing feeding frequency of sheep from 1 to 6 times had no effect on total and cellulolytic rumen bacteria population, which supports the lack of effect of diet delivery frequency on in sacco ruminal DM degradability parameters.

\section{Milk Production and Milk Composition}

Data of milk production and milk composition are presented in Table 6. Frequency of diet delivery had no effect on yield of milk, milk fat, or milk protein, which averaged 44.5, 1.65, and $1.44 \mathrm{~kg} / \mathrm{d}$, respectively. Consequently, production of FCM and ECM averaged 42.5 and $46.3 \mathrm{~kg} / \mathrm{d}$, respectively, and neither was affected by the experimental treatment. Concentrations of fat, protein, and lactose in milk were not affected by frequency of diet delivery. In this study, the lack of effect of frequency of diet delivery was consistent with no change in DMI. In agreement, other studies reported no effect of increasing frequency of diet delivery to dairy cows on yield of milk, milk fat, or milk protein (Robinson and Sniffen, 1985; Dhiman et al., 2002; Hart et al., 2014). However, an increase in milk fat or milk protein yield, or both, with increasing frequency of diet delivery has been reported when the concentrate percentage in the TMR exceeded $50 \%$ or the diet was 
Table 6. Milk production and milk composition in lactating cows receiving the diet once, twice, or 4 times daily

\begin{tabular}{|c|c|c|c|c|}
\hline \multirow[b]{2}{*}{ Item } & \multicolumn{3}{|c|}{ Daily frequency of diet delivery } & \multirow[b]{2}{*}{ SEM } \\
\hline & Once & Twice & 4 Times & \\
\hline \multicolumn{5}{|l|}{ Production $(\mathrm{kg} / \mathrm{d})$} \\
\hline Milk & 44.6 & 44.7 & 44.2 & 1.48 \\
\hline $4 \% \mathrm{FCM}^{1}$ & 42.4 & 42.7 & 42.4 & 1.48 \\
\hline $\mathrm{ECM}^{2}$ & 46.2 & 46.4 & 46.2 & 1.56 \\
\hline \multicolumn{5}{|l|}{ Composition (\%) } \\
\hline Fat & 3.66 & 3.71 & 3.75 & 0.089 \\
\hline Protein & 3.24 & 3.23 & 3.26 & 0.049 \\
\hline Lactose & 4.64 & 4.63 & 4.64 & 0.038 \\
\hline MUN (mg/dL) & $14.1^{\mathrm{b}}$ & $14.2^{\mathrm{ab}}$ & $14.7^{\mathrm{a}}$ & 0.41 \\
\hline $\operatorname{SCC}\left(10^{3} / \mathrm{mL}\right)$ & 70.6 & 63.3 & 56.7 & 18.63 \\
\hline \multicolumn{5}{|l|}{ Yield (kg/d) } \\
\hline Fat & 1.64 & 1.66 & 1.65 & 0.065 \\
\hline Protein & 1.44 & 1.44 & 1.44 & 0.048 \\
\hline Lactose & 2.07 & 2.07 & 2.05 & 0.075 \\
\hline \multicolumn{5}{|l|}{ Feed efficiency } \\
\hline Milk/DMI & 1.69 & 1.72 & 1.68 & 0.059 \\
\hline $\mathrm{FCM} / \mathrm{DMI}$ & 1.60 & 1.64 & 1.61 & 0.054 \\
\hline $\mathrm{ECM} / \mathrm{DMI}$ & 1.74 & 1.78 & 1.76 & 0.056 \\
\hline Milk N/N intake & 0.304 & 0.312 & 0.312 & 0.009 \\
\hline
\end{tabular}

based mainly on corn silage (Yang and Varga, 1989; Shabi et al., 1999). In this study, the dietary concentrates proportion was $44 \%$, and corn silage was $45 \%$ of the dietary forage component. Thus it is possible that the effect of frequency of diet delivery on milk protein and fat contents is more pronounced if dairy cows are fed high-concentrate than low-concentrate diets.

Compared with once daily, delivering the diet 4 times daily increased $(P=0.03)$ MUN concentration, but no differences were observed when compared with deliver- ing the diet twice daily. Previous studies reported no effect of frequency of diet delivery on MUN concentration (Dhiman et al., 2002; Mäntysaari et al., 2006; Macmillan et al., 2017). Milk production efficiency (kg of ECM $/ \mathrm{kg}$ of DMI) and milk $\mathrm{N}$ efficiency (g of milk $\mathrm{N} / \mathrm{g}$ of $\mathrm{N}$ intake) averaged 1.76 and 0.31 , respectively, and were not affected by frequency of diet delivery. Other studies reported no effect of frequency of diet delivery on milk production efficiency (Dhiman et al., 2002) or milk N efficiency (Judy et al., 2018).

Table 7. Enteric methane production in lactating cows receiving the diet once, twice, or four times daily

\begin{tabular}{|c|c|c|c|c|}
\hline \multirow[b]{2}{*}{ Item } & \multicolumn{3}{|c|}{ Daily frequency of diet delivery } & \multirow[b]{2}{*}{ SEM } \\
\hline & Once & Twice & 4 Times & \\
\hline $\mathrm{DMI}^{1}(\mathrm{~kg} / \mathrm{d})$ & 27.3 & 26.5 & 26.5 & 0.58 \\
\hline \multicolumn{5}{|l|}{$\mathrm{CH}_{4}$} \\
\hline $\mathrm{g} / \mathrm{d}$ & 526 & 536 & 540 & 17.2 \\
\hline $\mathrm{g} / \mathrm{kg}$ of DMI & $19.3^{\mathrm{b}}$ & $20.3^{\mathrm{a}}$ & $20.4^{\mathrm{a}}$ & 0.71 \\
\hline $\mathrm{g} / \mathrm{kg}$ of $\mathrm{OM}$ digested $^{2}$ & $8.34^{\mathrm{b}}$ & $8.78^{\mathrm{a}}$ & $8.78^{\mathrm{a}}$ & 0.312 \\
\hline$\%$ of GE intake ${ }^{3}$ & $5.75^{\mathrm{b}}$ & $6.06^{\mathrm{a}}$ & $6.06^{\mathrm{a}}$ & 0.206 \\
\hline $\mathrm{g} / \mathrm{kg}$ of $\mathrm{milk}^{4}$ & 11.9 & 12.2 & 12.6 & 0.70 \\
\hline $\mathrm{g} / \mathrm{kg}$ of $\mathrm{ECM}^{4}$ & 11.5 & 11.7 & 11.9 & 0.55 \\
\hline
\end{tabular}




\section{Methane Production}

Studies on the effect of frequency of diet delivery on enteric $\mathrm{CH}_{4}$ emissions of dairy cows are scarce. In this study, interactions between treatments and measurement days were not significant for $\mathrm{CH}_{4}$ emission measurements. Therefore, only averages across measurement days are presented in Table 7. Dry matter intake determined when cows were housed in the chambers averaged $26.8 \mathrm{~kg} / \mathrm{d}$ and was not affected $(P=0.19)$ by feeding frequency.

Daily enteric $\mathrm{CH}_{4}$ emissions averaged $534 \mathrm{~g} / \mathrm{d}$ and were not affected by frequency of diet delivery. This level of emission is close to those reported in our previous studies for cows with similar DMI (Benchaar et al., 2014; Cherif et al., 2018). Relative to DMI, GE intake, or $\mathrm{OM}$ digested, $\mathrm{CH}_{4}$ emissions were similar between cows receiving the diet twice or 4 times daily, averaging $20.4 \mathrm{~g} / \mathrm{kg}$ of DMI, $6.06 \%$ of GE intake, and $8.78 \mathrm{~g} / \mathrm{kg}$ of $\mathrm{OM}$ digested, respectively. However, delivering the diet once daily reduced $(P \leq 0.04) \mathrm{CH}_{4}$ emissions to $19.3 \mathrm{~g} / \mathrm{kg}$ of DMI, $5.75 \%$ of GE intake, and $8.34 \mathrm{~g} / \mathrm{kg}$ of OM digested, respectively, compared with delivering the diet twice or 4 times daily. This decline in $\mathrm{CH}_{4}$ emissions was not, however, associated with changes in nutrient intake and digestibility.

According to Nocek and Braund (1985), delivering the diet once daily to dairy cows did not affect DMI, but increased daytime (0600 to $1800 \mathrm{~h}$ ) rate of intake $(1.01 \mathrm{~kg}$ of $\mathrm{DM} / \mathrm{h})$ compared with delivering the diet 4 times daily $(0.91 \mathrm{~kg} / \mathrm{h})$. Similarly, DeVries et al. (2005) reported that increasing frequency of diet delivery reduced duration of feed consumption after diet delivery and increased daily feeding time, without affecting DMI. Also, Mäntysaari et al. (2006) reported that delivering the diet once daily induced a large peak of feed intake after diet delivery, whereas delivering the diet 5 times daily induced smaller peaks of feed intake that coincided with diet delivery. Based on the findings of these studies, it can be speculated that delivering the diet once daily may have increased the first meal size, which would have increased passage rate and reduced extent of rumen fermentation of the diet compared with cows receiving the diet twice or 4 times daily. Consequently, this reduced $\mathrm{CH}_{4}$ emissions expressed on DM, $\mathrm{GE}$, or digested $\mathrm{OM}$ intake bases in cows receiving the diet once daily compared with cows receiving the diet twice or 4 times daily. Other studies have demonstrated an inverse relationship between enteric $\mathrm{CH}_{4}$ production ( $\mathrm{g} / \mathrm{kg}$ of DMI or \% of GE intake) and ruminal passage rates (Okine et al., 1989; Goopy et al., 2014; Hammond et al., 2014). In agreement, Crompton et al. (2011) reported numerically lower $\mathrm{CH}_{4}$ emissions ( $\mathrm{g} / \mathrm{kg}$ of DMI) in cows receiving a diet ad libitum once per day versus twice or 4 times daily. However, studies that restricted DMI in cows reported no effect of frequency of diet delivery on $\mathrm{CH}_{4}$ production expressed in grams per day or grams per kilogram of DMI (Jonker et al., 2014; Judy et al., 2018).

In the current study, the lower enteric $\mathrm{CH}_{4}(\mathrm{~g} / \mathrm{kg}$ of DMI) in cows receiving the diet once daily compared with cows receiving the diet twice daily was associated with lower numbers of protozoa in cows receiving the diet once daily. Enteric $\mathrm{CH}_{4}$ production has been positively associated with total protozoa and entodiniomorph populations in the rumen (Hegarty, 1999; Guyader et al., 2014). An increase in passage rate would reduce protozoa population in the rumen according to Franzolin and Dehority (1996) and Janssen (2010). In the present study, the decline in $\mathrm{CH}_{4}$ yield $(\mathrm{g} / \mathrm{kg}$ of DMI) in cows receiving the diet once daily versus 4 times daily was associated with a decreased acetate molar proportion at 2,3, and $4 \mathrm{~h}$ after the a.m. meal. Delivering the diet 4 times daily compared with once daily may have increased rumen retention of $\mathrm{OM}$ and allowed more extensive fiber degradation in the rumen, resulting in higher acetate molar proportion at 2,3 , and $4 \mathrm{~h}$ after the a.m. meal. Increased acetate production in the rumen would liberate more hydrogen for methanogenesis (Boadi et al., 2004; Beauchemin et al., 2009).

When expressed on a milk production basis, $\mathrm{CH}_{4}$ emissions were not affected by frequency of diet delivery (average of $11.7 \mathrm{~g}$ of $\mathrm{CH}_{4} / \mathrm{kg}$ of $\mathrm{ECM}$ ). Similarly, Judy et al. (2018) reported no effect of frequency (once or twice daily) of diet delivery to Jersey cows on $\mathrm{CH}_{4}$ emissions expressed on a milk production basis. Crompton et al. (2011) reported a numerical increase in $\mathrm{CH}_{4}$ emissions ( $\mathrm{g} / \mathrm{kg}$ of milk) when frequency of diet delivery to cows increased.

Effect of frequency of diet delivery on diurnal variation in rate of $\mathrm{CH}_{4}$ production $(\mathrm{g} / \mathrm{h})$ is presented in Figure 5, and diurnal enteric $\mathrm{CH}_{4}$ production $(\mathrm{g} / \mathrm{h})$ kinetic parameters are presented in Table 8. Initial rate of $\mathrm{CH}_{4}$ production before the a.m. meal $(0930 \mathrm{~h})$ was similar between treatments and averaged $18.1 \mathrm{~g} / \mathrm{h}$. Regardless of frequency of diet delivery, rate of $\mathrm{CH}_{4}$ production increased after each diet delivery. Similarly, Crompton et al. (2011), Jonker et al. (2014), and Judy et al. (2018) reported that peaks of $\mathrm{CH}_{4}$ production rate coincide with frequency of diet delivery. In cows receiving the diet once per day, the rate of $\mathrm{CH}_{4}$ emission peaked $(25.8 \mathrm{~g} / \mathrm{h}) 1.79 \mathrm{~h}$ after the a.m. meal $(0930 \mathrm{~h})$ and then declined at a rate of $0.017 / \mathrm{h}$. In cows receiving the diet twice daily, $\mathrm{CH}_{4}$ production rate peaked $(24.5 \mathrm{~g} / \mathrm{h}) 2.21 \mathrm{~h}$ after the a.m. meal and then 


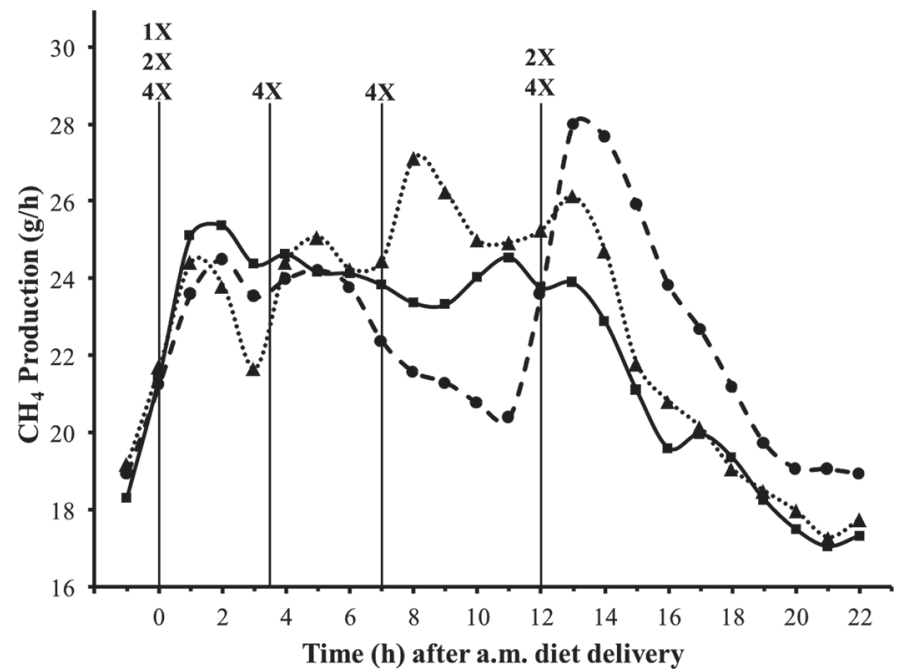

Figure 5. Daily enteric $\mathrm{CH}_{4}$ emissions in lactating cows receiving the diet once $(1 \mathrm{X} ; \mathbf{\square})$, twice $(2 \mathrm{X} ; \boldsymbol{\bullet})$, or 4 times $(4 \mathrm{X} ; \mathbf{\Delta})$ daily.

declined at a rate of $0.023 / \mathrm{h}$. Rate of $\mathrm{CH}_{4}$ production then peaked again $(28.1 \mathrm{~g} / \mathrm{h}) 1.06 \mathrm{~h}$ after the p.m. diet delivery $(2130 \mathrm{~h})$ and declined at a rate of $0.064 / \mathrm{h}$. In cows receiving the diet 4 times a day, $\mathrm{CH}_{4}$ production rate peaked $(24.6 \mathrm{~g} / \mathrm{h}) 1.05 \mathrm{~h}$ after the first diet delivery $(0930 \mathrm{~h})$ and then declined at a rate of $0.099 / \mathrm{h}$. Methane production rate peaked $(25.2 \mathrm{~g} / \mathrm{h}) 0.87 \mathrm{~h}$ after the second diet delivery $(1300 \mathrm{~h})$ and then declined at a rate of $0.030 / \mathrm{h}$. After the third diet delivery (1630 $\mathrm{h}), \mathrm{CH}_{4}$ production rate peaked $(27.1 \mathrm{~g} / \mathrm{h}) 0.61 \mathrm{~h}$ after diet delivery and then declined at a rate of $0.029 / \mathrm{h}$. Methane production rate peaked $(26.2 \mathrm{~g} / \mathrm{h}) 0.60 \mathrm{~h}$ after the fourth diet delivery $(2130 \mathrm{~h})$ and then declined at a rate of $0.098 / \mathrm{h}$. In our study, time (h) from diet delivery to peak $\mathrm{CH}_{4}$ production ranged from 0.60 to $2.21 \mathrm{~h}$, which is similar to the range of 0.66 to $2.00 \mathrm{~h}$ reported by Crompton et al. (2011). In accordance with our observations, Crompton et al. (2011) and Jonker et al. (2014) reported a decrease in time (h) to reach peak $\mathrm{CH}_{4}$ production after diet delivery, whereas $\mathrm{CH}_{4}$ production rate $(\mathrm{g} / \mathrm{h})$ after the peak declines more rapidly as frequency of diet delivery increases. In summary, for
$\mathrm{CH}_{4}$ production, time (h) to reach peak declined with increasing frequency of diet delivery and averaged 1.79, 1.64 , and $0.78 \mathrm{~h}$ when diets were delivered once, twice, and 4 times daily, respectively. Peak $\mathrm{CH}_{4}$ production rate $(\mathrm{g} / \mathrm{h})$ averaged $25.8,26.3$, and $25.7 \mathrm{~g} / \mathrm{h}$ when diets were delivered once, twice, and 4 times daily, respectively. Rate of decline of $\mathrm{CH}_{4}$ production after the peak (per h) increased with increasing frequency of diet delivery and averaged $0.017,0.044$, and $0.064 / \mathrm{h}$ when diets were delivered once, twice, and 4 times daily, respectively.

\section{Nitrogen Excretion}

Daily fecal and urinary outputs averaged $7.7 \mathrm{~kg}$ $\mathrm{DM} / \mathrm{d}$ and $27.2 \mathrm{~kg} / \mathrm{d}$, respectively, and were not influenced by frequency of diet delivery. Fecal $\mathrm{N}$ excretion averaged $233 \mathrm{~g} / \mathrm{d}$ and $32 \%$ of $\mathrm{N}$ intake and was not affected by frequency of diet delivery (Table 9). Nitrogen excretion in urine expressed in grams per day tended $(P=0.08)$ to be higher for cows receiving the diet 4 times daily compared with twice daily, but was not different from cows receiving the diet once daily. When expressed as a percentage of $\mathrm{N}$ intake, urinary $\mathrm{N}$ excretion was higher $(P=0.05)$ for cows receiving the diet 4 times daily versus once and twice daily, with no differences between delivering the diet once or twice daily. Total $\mathrm{N}$ excretion expressed as grams per day was not affected by frequency of diet delivery (averaged 483 $\mathrm{g} / \mathrm{d})$. When expressed as a percentage of $\mathrm{N}$ intake, total $\mathrm{N}$ excretion was higher $(P=0.04)$ when cows received the diet 4 times daily versus once or twice daily, with no differences between delivering the diet once or twice daily. In agreement, Judy et al. (2018) reported that diet delivery to cows once or twice per day had no effect on fecal or urinary $\mathrm{N}$ excretion.

The higher urinary and total $\mathrm{N}$ excretion (as a proportion of $\mathrm{N}$ intake) in cows receiving the diet 4 times daily compared with cows receiving the diet once or twice daily is in agreement with higher MUN in cows receiving the diet 4 times daily. Increasing frequency of diet delivery increases salivary secretions (Ruckebusch,

Table 8. Diurnal enteric $\mathrm{CH}_{4}$ production $(\mathrm{g} / \mathrm{h})$ kinetic parameters in lactating cows receiving the diet once, twice, or 4 times daily

\begin{tabular}{|c|c|c|c|c|c|}
\hline $\begin{array}{l}\text { Daily frequency } \\
\text { of diet delivery }\end{array}$ & $\begin{array}{l}\text { Time of diet delivery } \\
(\mathrm{hhmm})\end{array}$ & $\begin{array}{c}\text { Initial } \mathrm{CH}_{4} \text { production } \\
\text { rate }(\mathrm{g} / \mathrm{h})\end{array}$ & $\begin{array}{l}\text { Time } \\
\text { to peak }(\mathrm{h})\end{array}$ & $\begin{array}{c}\text { Peak } \mathrm{CH}_{4} \\
\text { production rate }(\mathrm{g} / \mathrm{h})\end{array}$ & $\begin{array}{l}\text { Rate of decline } \\
\quad(\text { per h) }\end{array}$ \\
\hline Once & 0930 & 18.2 & 1.79 & 25.8 & 0.017 \\
\hline \multirow[t]{3}{*}{4 Times } & 0930 & 18.1 & 1.05 & 24.4 & 0.099 \\
\hline & 1300 & 21.7 & 0.87 & 25.2 & 0.030 \\
\hline & 1630 & 24.0 & 0.61 & 27.1 & 0.029 \\
\hline
\end{tabular}


Table 9. Nitrogen excretion in feces and urine of lactating cows receiving the diet once, twice, or 4 times daily

\begin{tabular}{|c|c|c|c|c|}
\hline \multirow[b]{2}{*}{ Item } & \multicolumn{3}{|c|}{ Frequency of diet delivery } & \multirow[b]{2}{*}{ SEM } \\
\hline & Once & Twice & 4 Times & \\
\hline Intake N (g/d) & 744 & 723 & 720 & 15.2 \\
\hline \multicolumn{5}{|l|}{ Fecal N } \\
\hline $\mathrm{g} / \mathrm{d}$ & 238 & 229 & 231 & 7.6 \\
\hline$\%$ of $\mathrm{N}$ intake & 31.9 & 31.7 & 32.1 & 0.62 \\
\hline \multicolumn{5}{|l|}{ Urinary $\mathrm{N}$} \\
\hline $\mathrm{g} / \mathrm{d}$ & $251^{\mathrm{AB}}$ & $245^{\mathrm{B}}$ & $254^{\mathrm{A}}$ & 6.8 \\
\hline$\%$ of $\mathrm{N}$ intake & $34.0^{\mathrm{b}}$ & $33.9^{\mathrm{b}}$ & $35.6^{\mathrm{a}}$ & 0.93 \\
\hline \multicolumn{5}{|c|}{ Total N excretion } \\
\hline $\mathrm{g} / \mathrm{d}$ & 490 & 474 & 486 & 11.3 \\
\hline$\%$ of $\mathrm{N}$ intake & $65.9^{\mathrm{b}}$ & $65.6^{\mathrm{b}}$ & $67.7^{\mathrm{a}}$ & 1.02 \\
\hline \multicolumn{5}{|l|}{ Retained N } \\
\hline $\mathrm{g} / \mathrm{d}$ & 27.89 & 23.26 & 9.39 & 7.342 \\
\hline$\%$ of $\mathrm{N}$ intake & 3.65 & 3.17 & 1.07 & 0.977 \\
\hline
\end{tabular}

$\overline{\mathrm{a}, \mathrm{b}}$ Means within rows with different lowercase superscripts differ $(P<0.05)$.

${ }^{\mathrm{A}, \mathrm{B}}$ Means within rows with different uppercase superscripts tended to differ $(P=0.08)$.

1988; Beauchemin, 2018) and consequently increases urea recycling into the rumen. According to Lapierre and Lobley (2001), $67 \%$ of the ruminal $\mathrm{NH}_{3}$ pool originates from BUN, of which $47 \%$ are provided through saliva secretions. If urea $\mathrm{N}$ is not used for microbial protein synthesis, it will be reabsorbed, transferred to the liver, and excreted in urine. Because the diet used in this study provides a sufficient concentration of RDP (Table 1; NRC, 2001), excess contribution of urea from saliva generated by treatment effect is likely to be excreted in urine. However, the differences between treatments in MUN and urinary $\mathrm{N}$ excretion $(\leq 4 \%)$ are too small to have any biological significance.

Cabrita et al. (2006) reported that increasing frequency of diet delivery would reduce $\mathrm{N}$ excretion in urine through reduced daily fluctuation of ruminal $\mathrm{NH}_{3}$ concentration. The contrary was observed in this study when cows received the diet 4 times daily versus once or twice daily. It should be recognized that ruminal fluid sampling in this study encompassed the first 8 $\mathrm{h}$ after the a.m. meal and did not include the entire daily fluctuation of $\mathrm{NH}_{3}$ concentration. This may explain different responses to treatments in ruminal $\mathrm{NH}_{3}$ concentrations, MUN, and urine N excretion. Nitrogen retention was not affected by frequency of diet delivery (averaged $20 \mathrm{~g} / \mathrm{d}$ and $2.6 \% \mathrm{~N}$ intake).

\section{Chemical Composition of the Mixture of Feces and Urine and Manure Methane Emissions}

Amounts excreted and chemical composition of feces and urine mixture are presented in Table 10. Quantity of VS averaged $6.9 \mathrm{~kg} / \mathrm{d}$ and was not affected by frequency of diet delivery. This is consistent with the absence of treatment effect on OM intake and digestibility. Quantities of VS observed in this study are within the values predicted by equation 10.24 in Tier 2 of IPCC (2006), which averaged $7.3 \mathrm{~kg} / \mathrm{d}$.

Maximal $\mathrm{CH}_{4}$ emission potential averaged $148 \mathrm{~L} / \mathrm{kg}$ of VS and was not affected by frequency of diet delivery, which was consistent with the absence of treatment effect on VS and NDF excreted (Table 10). In this study, the observed values of maximal $\mathrm{CH}_{4}$ production potential of manure are within the range of values (85 to 197 $\mathrm{L} / \mathrm{kg}$ of VS) observed in our previous studies (Massé et al., 2016; Benchaar and Hassanat, 2019; Hassanat and

Table 10. Volatile solids of the mixture of urine and feces, maximal methane production potential of incubated manure of lactating cows receiving the diet once, twice, or 4 times daily

\begin{tabular}{lcccc}
\hline & \multicolumn{3}{c}{$\begin{array}{c}\text { Daily frequency } \\
\text { of diet delivery }\end{array}$} & \\
\cline { 2 - 3 } Item & Once & Twice & 4 Times & SEM \\
\hline Volatile solids & & & & \\
$\mathrm{kg} / \mathrm{d}$ & 6.85 & 7.16 & 6.64 & 0.354 \\
$\quad$ of $\mathrm{DM}$ & 83.7 & 83.1 & 82.3 & 0.55 \\
$\mathrm{NDF}(\%$ of $\mathrm{DM})$ & 44.8 & 44.6 & 44.5 & 1.18 \\
Maximal $\mathrm{CH}_{4}$ production $(\mathrm{L} / \mathrm{kg}$ of volatile solids) & 155 & 164 & 125 & 14.7 \\
\hline
\end{tabular}


Benchaar, 2019) under similar experimental conditions (17 wk of anaerobic incubation at $20^{\circ} \mathrm{C}$ ). According to Environment Canada (2015), maximal $\mathrm{CH}_{4}$ emission potential of manure from dairy cattle varies widely (100 to $240 \mathrm{~L} / \mathrm{kg}$ of VS).

\section{CONCLUSIONS}

Under the experimental condition of the present study, diet delivery to dairy cows once, twice, or 4 times per day had no effect on DMI, nutrient digestion, ruminal $\mathrm{pH}$, milk production, or milk composition. Methane production, expressed as a percentage of GE intake was lower for cows fed once daily versus cows fed twice or 4 times daily. Enteric $\mathrm{CH}_{4}$ production peaked after each meal and then declined after, with a more rapid decline rate when frequency of diet delivery increased. Diet delivery 4 times daily resulted in higher urinary $\mathrm{N}$ excretion (\% of $\mathrm{N}$ intake) compared with delivering the diet once or twice daily. Manure maximal $\mathrm{CH}_{4}$ emission potential was not affected by frequency of diet delivery.

\section{ACKNOWLEDGMENTS}

The authors are grateful for the efforts of Lisa Crote$\mathrm{au}$ and Sylvie Provencher (technical assistance), Steve Methot (help with statistical analysis), and the barn crew (care for animal) from the Sherbrooke Research and Development Centre (Agriculture and Agri-Food Canada, Sherbrooke, Quebec). Funding from Agriculture and Agri-Food Canada (Ottawa, Ontario) made this work possible. The authors have not stated any conflicts of interest.

\section{REFERENCES}

AOAC International. 2005. Official Methods of Analysis. 18th ed. AOAC International, Arlington, VA.

Beauchemin, K., T. A. McAllister, and S. McGinn. 2009. Dietary mitigation of enteric methane from cattle. Perspect. Agric. Vet. Sci. Nutr. Nat. Resour. 4:1-18. https://doi.org/10.1079/ PAVSNNR20094035.

Beauchemin, K. A. 2018. Invited review: Current perspectives on eating and rumination activity in dairy cows. J. Dairy Sci. 101:47624784. https://doi.org/10.3168/jds.2017-13706.

Benchaar, C., and F. Hassanat. 2019. Methane emissions of stored manure from dairy cows fed conventional or brown midrib corn silage. J. Dairy Sci. 102:10632-10638. https://doi.org/10.3168/jds .2019-16822.

Benchaar, C., F. Hassanat, R. Gervais, P. Y. Chouinard, C. Julien, H. V. Petit, and D. I. Massé. 2013. Effects of increasing amounts of corn dried distillers grains with solubles in dairy cow diets on methane production, ruminal fermentation, digestion, $\mathrm{N}$ balance, and milk production. J. Dairy Sci. 96:2413-2427. https://doi.org/ $10.3168 /$ jds.2012-6037.

Benchaar, C., F. Hassanat, R. Gervais, P. Y. Chouinard, H. V. Petit, and D. I. Masse. 2014. Methane production, digestion, ruminal fermentation, nitrogen balance, and milk production of cows fed corn silage- or barley silage-based diets. J. Dairy Sci. 97:961-974. https://doi.org/10.3168/jds.2013-7122.

Benchaar, C., F. Hassanat, R. Martineau, and R. Gervais. 2015. Linseed oil supplementation to dairy cows fed diets based on red clover silage or corn silage: Effects on methane production, rumen fermentation, nutrient digestibility, $\mathrm{N}$ balance, and milk production. J. Dairy Sci. 98:7993-8008. https://doi.org/10.3168/jds.2015 $-9398$.

Boadi, D., C. Benchaar, J. Chiquette, and D. Massé. 2004. Mitigation strategies to reduce enteric methane emissions from dairy cows: Update review. Can. J. Anim. Sci. 84:319-335. https://doi.org/10 .4141/A03-109.

Bragg, D. S. A., M. R. Murphy, and C. L. Davis. 1986. Effect of source of carbohydrate and frequency of feeding on rumen parameters in dairy steers. J. Dairy Sci. 69:392-402. https://doi.org/10.3168/jds .S0022-0302(86)80417-9.

Brask, M., P. Lund, M. R. Weisbjerg, A. L. F. Hellwing, M. Poulsen, M. K. Larsen, and T. Hvelplund. 2013. Methane production and digestion of different physical forms of rapeseed as fat supplements in dairy cows. J. Dairy Sci. 96:2356-2365. https://doi.org/ 10.3168/jds.2011-5239.

Cabrita, A. R. J., R. J. Dewhurst, J. M. F. Abreu, and A. J. M. Fonseca. 2006. Evaluation of the effects of synchronising the availability of $\mathrm{N}$ and energy on rumen function and production responses of dairy cows-A review. Anim. Res. 55:1-24. https://doi.org/10 .1051/animres:2005045.

Canadian Council on Animal Care. 2009. CCAC guidelines on: the care and use of farm animals in research, teaching and testing. Canadian Council on Animal Care, Ottawa, ON, Canada.

Cecava, M. J., N. R. Merchen, L. L. Berger, and D. R. Nelson. 1990. Effect of energy level and feeding frequency on site of digestion and postruminal nutrient flows in steers. J. Dairy Sci. 73:24702479. https://doi.org/10.3168/jds.S0022-0302(90)78932-1.

Cherif, C., F. Hassanat, S. Claveau, J. Girard, R. Gervais, and C. Benchaar. 2018. Faba bean (Vicia faba) inclusion in dairy cow diets: Effect on nutrient digestion, rumen fermentation, nitrogen utilization, methane production, and milk performance. J. Dairy Sci. 101:8916-8928. https://doi.org/10.3168/jds.2018-14890 http:/ /dx.doi.org/doi:10.3168/jds.2018-14890.

Crompton, L. A., J. A. N. Mills, C. K. Reynolds, and J. France. 2011. Fluctuations in methane emission in response to feeding pattern in lactating dairy cows. Pages $176-180$ in Modelling Nutrient Digestion and Utilisation in Farm Animals. D. Sauvant, J. Van Milgen, P. Faverdin, and N. Friggens, ed. Wageningen Academic Publishers, Wageningen, the Netherlands.

Crossley, R. E., A. Harlander-Matauschek, and T. J. DeVries. 2018. Mitigation of variability between competitively fed dairy cows through increased feed delivery frequency. J. Dairy Sci. 101:518 529. https://doi.org/10.3168/jds.2017-12930.

Dehority, B. A. 1993. Laboratory Manual for Classification and Morphology of Rumen Ciliate Protozoa. CRC Press Inc., Boca Raton, FL.

Dehority, B. A., and P. A. Tirabasso. 2001. Effect of feeding frequency on bacterial and fungal concentrations, $\mathrm{pH}$, and other parameters in the rumen. J. Anim. Sci. 79:2908-2912. https://doi.org/10 $.2527 / 2001.79112908 x$.

DeVries, T. J., and M. A. G. von Keyserlingk. 2005. Time of feed delivery affects the feeding and lying patterns of dairy cows. J. Dairy Sci. 88:625-631. https://doi.org/10.3168/jds.S0022-0302(05)72726 -0 .

DeVries, T. J., M. A. G. von Keyserlingk, and K. A. Beauchemin. 2005. Frequency of feed delivery affects the behavior of lactating dairy cows. J. Dairy Sci. 88:3553-3562. https://doi.org/10.3168/ jds.S0022-0302(05)73040-X.

Dhiman, T. R., M. S. Zaman, I. S. MacQueen, and R. L. Boman. 2002. Influence of corn processing and frequency of feeding on cow performance. J. Dairy Sci. 85:217-226. https://doi.org/10.3168/ jds.S0022-0302(02)74070-8.

Environment Canada. 2015. Greenhouse Gas Sources and Sinks in Canada, National Inventory Report 1990-2013, Part 2. Environment Canada, Ottawa, ON, Canada. 
Environment Canada. 2019. National Inventory Report 1990-2017: Greenhouse Gas Sources and Sinks in Canada-Executive Summary. Environment Canada, Ottawa, ON, Canada.

Falk, M., A. Münger, and F. Dohme-Meier. 2016. Technical note: A comparison of reticular and ruminal $\mathrm{pH}$ monitored continuously with 2 measurement systems at different weeks of early lactation. J. Dairy Sci. 99:1951-1955. https://doi.org/10.3168/jds.2015-9725.

Franzolin, R., and B. A. Dehority. 1996. Effect of prolonged highconcentrate feeding on ruminal protozoa concentrations. J. Anim. Sci. 74:2803-2809. https://doi.org/10.2527/1996.74112803x.

French, N., and J. J. Kennelly. 1990. Effects of feeding frequency on ruminal parameters, plasma insulin, milk yield, and milk composition in Holstein cows. J. Dairy Sci. 73:1857-1863. https://doi.org/ 10.3168/jds.S0022-0302(90)78866-2.

Froetschel, M. A., and H. E. Amos. 1991. Effects of dietary fiber and feeding frequency on ruminal fermentation, digesta water-holding capacity, and fractional turnover of contents. J. Anim. Sci. 69:1312-1321. https://doi.org/69:1312-1321.

Froetschel, M. A., A. C. Martin, H. E. Amos, and J. J. Evans. 1990. Effects of zinc sulfate concentration and feeding frequency on ruminal protozoal numbers, fermentation patterns and amino acid passage in steers. J. Anim. Sci. 68:2874-2884. https://doi.org/10 $.2527 / 1990.6892874 \mathrm{x}$.

Goopy, J. P., A. Donaldson, R. Hegarty, P. E. Vercoe, F. Haynes, M. Barnett, and V. H. Oddy. 2014. Low-methane yield sheep have smaller rumens and shorter rumen retention time. Br. J. Nutr. 111:578-585. https://doi.org/10.1017/S0007114513002936.

Guyader, J., M. Eugene, P. Noziere, D. P. Morgavi, M. Doreau, and C. Martin. 2014. Influence of rumen protozoa on methane emission in ruminants: A meta-analysis approach. Animal 8:1816-1825. https: //doi.org/10.1017/S1751731114001852.

Hammond, K. J., D. Pacheco, J. L. Burke, J. P. Koolaard, S. Muetzel, and G. C. Waghorn. 2014. The effects of fresh forages and feed intake level on digesta kinetics and enteric methane emissions from sheep. Anim. Feed Sci. Technol. 193:32-43. https://doi.org/ 10.1016/j.anifeedsci.2014.04.005.

Hart, K. D., B. W. McBride, T. F. Duffield, and T. J. DeVries. 2014. Effect of frequency of feed delivery on the behavior and productivity of lactating dairy cows. J. Dairy Sci. 97:1713-1724. https://doi .org/10.3168/jds.2013-7504.

Hassanat, F., and C. Benchaar. 2019. Methane emissions of manure from dairy cows fed red clover- or corn silage-based diets supplemented with linseed oil. J. Dairy Sci. 102:11766-11776. https://doi .org/10.3168/jds.2018-16014.

Hassanat, F., R. Gervais, and C. Benchaar. 2017. Methane production, ruminal fermentation characteristics, nutrient digestibility, nitrogen excretion, and milk production of dairy cows fed conventional or brown midrib corn silage. J. Dairy Sci. 100:2625-2636. https:// doi.org/10.3168/jds.2016-11862.

Hegarty, R. S. 1999. Reducing rumen methane emissions through elimination of rumen protozoa. Aust. J. Agric. Res. 50:1321-1327. https://doi.org/10.1071/AR99008.

IPCC. 2006. Emissions from livestock and manure management. In Guidelines for Green House Inventories, Vol. 4. United Nations Intergovernmental Panel on Climate Change (IPCC), Geneva, Switzerland.

Janssen, P. H. 2010. Influence of hydrogen on rumen methane formation and fermentation balances through microbial growth kinetics and fermentation thermodynamics. Anim. Feed Sci. Technol. 160:1-22. https://doi.org/10.1016/j.anifeedsci.2010.07.002.

Jonker, A., G. Molano, C. Antwi, and G. Waghorn. 2014. Feeding lucerne silage to beef cattle at three allowances and four feeding frequencies affects circadian patterns of methane emissions, but not emissions per unit of intake. Anim. Prod. Sci. 54:1350-1353. https://doi.org/10.1071/AN14235.

Judy, J. V., G. C. Bachman, T. M. Brown-Brandl, S. C. Fernando, K. E. Hales, P. S. Miller, R. R. Stowell, and P. J. Kononoff. 2018. Energy balance and diurnal variation in methane production as affected by feeding frequency in Jersey cows in late lactation. J. Dairy Sci. 101:10899-10910. https://doi.org/10.3168/jds.2018 $-14596$.
Keunen, J. E., J. C. Plaizier, L. Kyriazakis, T. F. Duffield, T. M. Widowski, M. I. Lindinger, and B. W. McBride. 2002. Effects of a subacute ruminal acidosis model on the diet selection of dairy cows. J. Dairy Sci. 85:3304-3313. https://doi.org/10.3168/jds .S0022-0302(02)74419-6.

King, M. T. M., R. E. Crossley, and T. J. DeVries. 2016. Impact of timing of feed delivery on the behavior and productivity of dairy cows. J. Dairy Sci. 99:1471-1482. https://doi.org/10.3168/jds.2015 $-9790$.

Klusmeyer, T. H., M. R. Cameron, G. C. McCoy, and J. H. Clark. 1990. Effects of feed processing and frequency of feeding on ruminal fermentation, milk production, and milk composition. J. Dairy Sci. 73:3538-3543. https://doi.org/10.3168/jds.S0022 $-0302(90) 79053-4$

Lapierre, H., and G. E. Lobley. 2001. Nitrogen recycling in the ruminant: A review. J. Dairy Sci. 84:E223-E236. https://doi.org/10 .3168/jds.S0022-0302(01)70222-6.

Le Liboux, S., and J. L. Peyraud. 1999. Effect of forage particle size and feeding frequency on fermentation patterns and sites and extent of digestion in dairy cows fed mixed diets. Anim. Feed Sci. Technol. 76:297-319. https://doi.org/10.1016/S0377-8401(98)00220-X.

Macmillan, K., X. Gao, and M. Oba. 2017. Increased feeding frequency increased milk fat yield and may reduce the severity of subacute ruminal acidosis in higher-risk cows. J. Dairy Sci. 100:1045-1054. https://doi.org/10.3168/jds.2016-11337.

Mäntysaari, P., H. Khalili, and J. Sariola. 2006. Effect of feeding frequency of a total mixed ration on the performance of high-yielding dairy cows. J. Dairy Sci. 89:4312-4320. https://doi.org/10.3168/ jds.S0022-0302(06)72478-X.

Massé, D. I., G. Jarret, F. Hassanat, C. Benchaar, and N. M. C. Saady. 2016. Effect of increasing levels of corn silage in an alfalfa-based dairy cow diet and of manure management practices on manure fugitive methane emissions. Agric. Ecosyst. Environ. 221:109-114. https://doi.org/10.1016/j.agee.2016.01.018.

McDonald, I. 1981. A revised model for the estimation of protein degradability in the rumen. J. Agric. Sci. 96:251-252. https://doi .org/10.1017/S0021859600032081.

Møller, H. B., V. Moset, M. Brask, M. R. Weisbjerg, and P. Lund. 2014. Feces composition and manure derived methane yield from dairy cows: Influence of diet with focus on fat supplement and roughage type. Atmos. Environ. 94:36-43. https://doi.org/10 .1016/j.atmosenv.2014.05.009.

Nocek, J. E., and D. G. Braund. 1985. Effect of feeding frequency on diurnal dry matter and water consumption, liquid dilution rate, and milk yield in first lactation. J. Dairy Sci. 68:2238-2247. https: //doi.org/10.3168/jds.S0022-0302(85)81096-1.

NRC (National Research Council). 2001. Nutrient Requirements for Dairy Cattle. National Academy Press, Washington, DC.

Ogimoto, K., and S. Imai. 1981. Techniques of rumen microbiology. Page 158 in Atlas of Rumen Microbiology. Japan Sci. Soc. Press, Tokyo, Japan.

Okine, E. K., G. W. Mathison, and R. T. Hardin. 1989. Effects of changes in frequency of reticular contractions on fluid and particulate passage rates in cattle. J. Anim. Sci. 67:3388-3396. https:// doi.org/10.2527/jas1989.67123388x.

Phillips, C. J. C., and M. I. Rind. 2001. The effects of frequency of feeding a total mixed ration on the production and behavior of dairy cows. J. Dairy Sci. 84:1979-1987. https://doi.org/10.3168/ jds.S0022-0302(01)74641-3.

Plaizier, J. C., J. E. Keunen, J. P. Walton, T. F. Duffield, and B. W. McBride. 2001. Effect of subacute ruminal acidosis on in situ digestion of mixed hay in lactating dairy cows. Can. J. Anim. Sci. 81:421-423. https://doi.org/10.4141/A00-106.

Robinson, P. H., and C. J. Sniffen. 1985. Forestomach and whole tract digestibility for lactating dairy cows as influenced by feeding frequency. J. Dairy Sci. 68:857-867. https://doi.org/10.3168/jds .S0022-0302(85)80903-6.

Ruckebusch, Y. 1988. Motility of the gastro-intestinal tract. Pages 64-107 in The Ruminant Animal: Digestive Physiology and Nutrition. D. C. Church, ed. Waveland Press, Prospect Heights, IL. 
Shabi, Z., A. Arieli, I. Bruckental, Y. Aharoni, S. Zamwel, A. Bor, and H. Tagari. 1998. Effect of the synchronization of the degradation of dietary crude protein and organic matter and feeding frequency on ruminal fermentation and flow of digesta in the abomasum of dairy cows. J. Dairy Sci. 81:1991-2000. https://doi.org/10.3168/ jds.S0022-0302(98)75773-X.

Shabi, Z., I. Bruckental, S. Zamwell, H. Tagari, and A. Arieli. 1999. Effects of extrusion of grain and feeding frequency on rumen fermentation, nutrient digestibility, and milk yield and composition in dairy cows. J. Dairy Sci. 82:1252-1260. https://doi.org/10.3168/ jds.S0022-0302(99)75348-8.

Thornley, J. H., and J. France. 2007. Mathematical Models in Agriculture: Quantitative Methods for the Plant, Animal and Ecological Sciences. 2nd ed. CABI International, Wallingford, UK.

Tyrrell, H. F., and J. T. Reid. 1965. Prediction of the energy value of cow's milk. J. Dairy Sci. 48:1215-1223. https://doi.org/10.3168/ jds.S0022-0302(65)88430-2.

Ulyatt, M. J., G. C. Waghorn, A. John, C. S. W. Reid, and J. Monro. 1984. Effect of intake and feeding frequency on feeding behaviour and quantitative aspects of digestion in sheep fed chaffed lucerne hay. J. Agric. Sci. 102:645-657. https://doi.org/10.1017/ S0021859600042192.

Van Soest, P. J., J. B. Robertson, and B. A. Lewis. 1991. Methods for dietary fiber, neutral detergent fiber, and nonstarch polysaccharides in relation to animal nutrition. J. Dairy Sci. 74:3583-3597. https://doi.org/10.3168/jds.S0022-0302(91)78551-2.

Weatherburn, M. 1967. Phenol-hypochlorite reaction for determination of ammonia. Anal. Chem. (Wash.) 39:971-974. https://doi .org/10.1021/ac60252a045.

Yang, C. M. J., and G. A. Varga. 1989. Effect of three concentrate feeding frequencies on rumen protozoa, rumen digesta kinetics, and milk yield in dairy cows. J. Dairy Sci. 72:950-957. https://doi .org/10.3168/jds.S0022-0302(89)79188-8.

\section{ORCIDS}

C. Benchaar ๑ https://orcid.org/0000-0002-8644-6892

F. Hassanat (1) https://orcid.org/0000-0002-2311-8234 